\title{
The Durable Differential Deterrent Effects of Strict Photo Identification Laws*
}

\author{
Justin Grimmer ${ }^{\dagger}$ \\ Department of Political Science \\ Stanford University \\ Jesse Yoder \\ Department of Political Science \\ Stanford University
}

May 20, 2020

\begin{abstract}
An increasing number of states have adopted laws that require voters to show photo identification to vote. We show that the differential effect of the laws on turnout among those who lack ID persists even after the laws are repealed. We leverage administrative data from North Carolina and a photo ID law in effect for a primary, but not the subsequent general, election. Using exact matching and a difference-in-differences design, we show that for the $3 \%$ of voters who lack ID in North Carolina, the ID law caused a 0.7 percentage point turnout decrease in the 2016 primary election relative to those with ID. After the law was suspended this effect persisted: those without ID were 2.6 percentage points less likely to turnout in the 2016 general election and 1.7 percentage points less likely to turnout in the 2018 general.
\end{abstract}

\footnotetext{
*Authors are listed in alphabetical order and contributed equally. For comments and suggestions, the authors thank Andy Hall, Jonathan Mummolo, Paul Sniderman, Sean Westwood, members of Stanford's Democracy and Polarization Lab, and participants at the 2019 Election Sciences, Reform, and Administration conference.

${ }^{\dagger}$ Justin Grimmer is a Professor in the Department of Political Science at Stanford University and Senior Fellow at the Hoover Institution (jgrimmer@stanford.edu; 616 Serra Mall, Stanford, CA 94305).

${ }^{\ddagger}$ Corresponding Author. Jesse Yoder is a Ph.D. Candidate in the Department of Political Science at Stanford University (yoderj@stanford.edu; 616 Serra Mall, Stanford, CA 94305).
} 
"The proposed [voter ID] law puts up barriers to voting that will trap honest voters in confusion and discourage them [...]."

- Roy Cooper, Governor of North Carolina (2018) ${ }^{1}$

\section{Introduction}

A growing number of states have enacted laws that require voters to show photo identification (ID) to cast a ballot. ${ }^{2}$ Meanwhile, a flurry of legal challenges and scholarly analyses have sought to estimate the effect of the voter ID laws. Do strict ID laws deter voters from turning out, and if so, how? In this paper we demonstrate that photo ID laws differentially deter voters without state identification, relative to voters with identification, while in place and continue to differentially deter voters even after those laws are repealed. The differential deterrent effect for individuals without state ID occurs while the law is in effect both because voters without a state ID are deterred from voting once they arrive at the polls, what we call a mechanical effect, and because voters without state ID decide to not turnout at all, a differential deterrent effect. Once the law is removed, the differential deterrent effect can persist because voters without ID may be unaware of the requirements for voting have changed.

To assess the persistent deterent effect of voter ID laws, we use administrative data from North Carolina and exploit variation in a photo ID law that was in effect for the 2016 primary election but not the 2016 general election and beyond. The North Carolina legislature passed a law in 2013 requiring photo ID to vote starting in the 2016 primary election. To inform voters of the law change, the North Carolina State Board of Elections (NCSBE) sent a mailer to all voters who lacked a state-issued ID (about $3 \%$ of registrants in North Carolina), informing them that photo identification would be required to vote. To assess the effect of this law, we use exact matching on a variety of individual characteristics,

\footnotetext{
${ }_{1}^{1}$ https://www.newsobserver.com/news/politics-government/article223103100.html

${ }^{2}$ http://www.ncsl.org/research/elections-and-campaigns/voter-id.aspx
} 
including turnout history prior to the ID law, and a difference-in-differences design, to find that the strict photo voter ID caused a 0.7 percentage point decline in turnout in the primary election among those who did not match to a state-issued ID, compared to those who did have state ID. After the primary election in July 2016 an appellate court overturned the photo ID law, removing the requirement for photo identification to vote. But there was no subsequent letter sent to inform voters that photo identification was no longer required.

The change in the law without notifying voters created confusion about what was necessary to vote and as a result the effect of the ID law persisted after the law was repealed. Even though the ID law was suspended, individuals without a state-issued ID were 2.6 percentage points less likely to turnout in the 2016 general election than voters with ID. This effect persisted beyond the 2016 election, though the magnitude of the effect decreased: in the 2018 general election individuals without valid identification were 1.7 percentage points less likely to turnout and there was no deterrent effect in the primary election. This pattern is consistent with the change in laws sowing confusion: the effect is concentrated among voters who participated occasionally in prior elections and have a low probability of participating in primaries.

The persistent effect of voter ID laws demonstrates the need to revisit common research designs used to assess the effect of voter ID laws. To assess the effects of voter ID laws scholars compare turnout in states that have voter ID requirements with those that do not, using either aggregate state-level turnout or self-reported turnout data (Erikson and Minnite 2009). Some designs have found no effect on turnout (Mycoff, Wagner, and Wilson 2009; Hood and Bullock 2012; Highton 2017; Cantoni and Pons 2019), while others have found negative effects on turnout (Alvarez, Bailey, and Katz 2008; Barreto, Nuño, and Sanchez 2009; Alvarez, Bailey, and Katz 2011; Hajnal, Lajevardi, and Nielson 2017). Yet, if the effect of voter ID laws persists, then states that are classified as "control" states after a law is repealed will still have voters affected by the law being in place. And as a result, the most common research designs will be biased towards finding no effect. 
The magnitude of the effects that we estimate also demonstrates that prior studies lack the appropriate data and statistical power to detect this effect. The voter ID law continued to deter voters, but our best estimate of the overall effect of voter ID laws on aggregate turnout is small enough to show that studies assessing the effect of voter ID laws on aggregate turnout lack the power to detect the effect of the laws. Using a simple set of assumptions to calculate the number of voters affected by the differential deterrent effect, we find the law caused approximately 5,110 individuals without identification to not vote in the 2016 general election. This accounts for approximately $0.1 \%$ of the total votes cast in the election. Designs that use aggregate level turnout rates or administrative data without information about who holds identification will fail to detect this change in turnout rates. And while other studies sometimes use survey research to learn who holds identification, this group is so small that it is difficult to estimate the effect with policy-relevant precision (Erikson and Minnite 2009; Grimmer et al. 2018). ${ }^{3}$

And our results suggest that debates and policy disputes about voter ID laws could dampen turnout, even when photo identification laws are removed. This has important implications for assessing turnout in states where voter ID laws are still actively debated. For example, in the wake of North Carolina's strict photo ID law being struck down in 2016, voters in North Carolina approved a ballot measure in November 2018 to amend the state constitution to require to require photo identification to vote. ${ }^{4}$ While the new requirements are already the subject of pending lawsuits, ${ }^{5}$ North Carolina Governor Roy Cooper signed a bill into law in March 2019 to delay the voter ID requirements until $2020{ }^{6}$ Given the turbulent nature of debates and implementation of voter ID laws along with our

\footnotetext{
${ }^{3}$ Many studies have used surveys to estimate the rate at which individuals have ID required to vote under different voter ID laws, often finding that rates of having inadequate photo ID under a strict photo ID requirement range from about 1 to 15 percent (Hood and Bullock 2008; Ansolabehere 2012; Barreto and Walker 2012; Beatty 2012; Hobby et al. 2015). These studies often find racial minorities are less likely to have ID compared to other registered voters.

${ }^{4}$ https://dashboard.ncleg.net/api/Services/BillSummary/2017/H1092-SMBK-165(sl)-v-4

${ }^{5}$ https://www . wunc.org/post/nc-naacp-challenges-new-voter-id-law-federal-court

${ }^{6}$ https://www.wfae.org/post/gov-cooper-signs-law-delay-voter-id\#stream/0
} 
findings, officials and researchers should carefully consider how these processes affect who votes, regardless of if or when these requirements are actually implemented.

\section{Voter ID Laws in North Carolina and Their Effect on Voter Turnout}

In 2013, North Carolina passed legislation to implement a strict photo voter ID law, beginning with the 2016 election. ${ }^{7}$ In accordance with the law, in 2015 the North Carolina State Board of Elections (NCSBE) generated a list of registered voters who did not match to a state-issued photo ID issued by the North Carolina Division of Motor Vehicles (DMV) at the time of the 2014 general election. ${ }^{8}$ Using this list, the NCSBE sent a mailer to each of these registrants, which stated that photo ID would be needed to vote in 2016, listed resources for obtaining free photo ID, and provided a postage pre-paid response card where recipients could indicate they needed assistance in acquiring a photo ID. ${ }^{9}$ Registered voters were required to show an acceptable form of photo ID to cast a ballot, which included a North Carolina driver's license, U.S. passport, or U.S. military ID card, among others. If voters were unable to present acceptable photo ID, they could cast a provisional ballot, which would only be counted if the voter took additional action after Election Day by presenting ID in person at their County Board of Elections. ${ }^{10}$ In July 2016, after the 2016 primary but before the general election, the 4th U.S. Circuit Court of Appeals overturned the voter ID

\footnotetext{
7 https://www.ncleg.net/Sessions/2013/Bills/House/PDF/H589v9.pdf

${ }^{8}$ https://moritzlaw.osu.edu/electionlaw/litigation/documents/NAACPPlaintiffsPreTrialBrief011916. pdf

${ }^{9}$ https://www.ncmd.uscourts.gov/sites/ncmd/files/opinions/13cv658moo_0.pdf.

${ }^{10}$ Along with their provisional ballot, voters could also complete a "reasonable impediment declaration" to indicate a reasonable impediment to obtaining photo ID (https://law.justia.com/codes/northcarolina/2015/chapter-163/article-14a/section-163-166.15). Voters also provide the last four digits of their social security number and date of birth, or a copy of a non-photo ID document. In the 2016 primary, 864 voters had their provisional ballots cast for lack of ID ultimately accepted under the reasonable impediment declaration (https://www.newsobserver.com/news/politics-government/ article222949830.html). For a full explanation of acceptable forms of ID and procedure for casting provisional ballots for lack of ID in North Carolina for the 2016 primary, see Hopkins et al. (2017).
} 
law, citing its discriminatory intent. ${ }^{11}$ After the ruling the ID law was not in place for the 2016 general election. While the court ruling blocked the enforcement of voter ID laws in the general election, it did not require a new letter to voters without identification to inform them that identification was no longer required to vote.

We use variation in the voter ID law's implementation for the 2016 primary and general elections to estimate the persistent effect of voter ID laws among those who lack state ID. The effect of the North Carolina law on those without state identification combines two distinct ways the laws could deter voters: a mechanical effect that occurs at the polls and an overall deterrent effect that causes individuals to not turnout at all.

Once the law was struck down by the appellate court the mechanical effect immediately is removed, but the differential deterrent effect remains until voters without state-issued identification learn about the change in rules about required identification. One impediment to learning about the change is that there was no official notice from the state: the appellate court struck down the law, but did not order a second letter sent to voters about the different requirements. Political campaigns or the media could provide information to voters, but this will necessarily be less likely to reach potential voters than the information from the NCSBE. For example, as we show in Appendix A.1 newspaper coverage of the voter ID law in both North Carolina and national news sources tended to occur when the appellate court decision was made, rather than immediately prior to election day when voters are most interested in the campaign.

We interpret our treatment effect as the differential effect of the law on those without state-issued identification, relative to those with a state ID. We focus on this interpretation because imposing a strict photo ID law could affect the turnout decision of all registered voters and our design is unable to address potential changes in voting behavior for individuals who hold valid identification. Individuals could be angered by the law increasing turnout among those who already hold valid identification (Valentino and Neuner 2017), campaigns

\footnotetext{
${ }^{11}$ http: //pdfserver.amlaw. com/nlj/7-29-16\%204th\%20Circuit $\% 20 N A A C P \% 20 v \% 20 N C$.pdf
} 
might exert compensatory effort to turn out individuals with valid ID, or increased controversy around the law might cause more voters to be more interested in the election. Our interpretation - as the differential effect of the law for those without identification - is necessarily different than the policy question of what turnout would have been if the voter ID law had never been put in place. As we explain below, we can impose plausible and transparent assumptions about the broader effect of the law to generate estimates for this different policy question. And our results provide important insights into who is deterred when the law is put into place.

Measuring Who Holds Identification To measure who lacks a state-issued ID, we combine administrative data from North Carolina voter files - which includes information on a voter's address, age, race, and turnout history in every primary and general election from 2008 to 2018 - with individual-level administrative data on who possesses a stateissued ID. ${ }^{12}$ We use the unique identifier the NCSBE generated to identify voters without identification, which we use to merge to the voter file to measure an individual's lack of ID.

Our measure of who might lack photo ID, then, is the list of voters who the NCSBE identified as possibly lacking ID through this matching process. We discuss possible sources of measurement error in Appendix Section A.2 and show that the measure error from this matching is likely to be small.

Table 1 shows descriptive statistics for the full voter file compared to registrants who do not match to an ID. About $3.0 \%$ of registrants fail to match, indicating that they might lack adequate ID to vote under the strict ID law. The composition of registrants without ID differs from the full voter file: those lacking ID have lower turnout on average, and they are more likely to be non-white as well as registered Democrats. The standard deviation of birth year is also larger among those without ID, which comports with previous survey work showing those who lack ID often tend to be young or elderly (e.g., Stewart III 2013).

${ }^{12}$ All of this information is publicly available and provided by the North Carolina State Board of Elections (NCSBE). 
Table 1 - Descriptive Statistics, Individual Level, 2008-2018.

\begin{tabular}{lcccc}
\hline \hline & $\begin{array}{c}\text { Mean } \\
(1)\end{array}$ & $\begin{array}{c}\text { Deviation } \\
(2)\end{array}$ & $\begin{array}{c}\text { Minimum } \\
(3)\end{array}$ & $\begin{array}{c}\text { Maximum } \\
(4)\end{array}$ \\
\hline & \multicolumn{2}{c}{ A. Full Voter File $(\#$ Voters $=6480423)$} \\
\cline { 2 - 5 } Voted & 0.382 & 0.486 & 0 & 1 \\
Hispanic & 0.020 & 0.139 & 0 & 1 \\
Black & 0.229 & 0.420 & 0 & 1 \\
White & 0.715 & 0.451 & 0 & 1 \\
Other Non-White & 0.036 & 0.186 & 0 & 1 \\
Democrat & 0.420 & 0.494 & 0 & 1 \\
Republican & 0.308 & 0.461 & 0 & 1 \\
Unaffiliated & 0.273 & 0.445 & 0 & 1 \\
Birth Year & 1966 & 18 & 1910 & 1999 \\
\cline { 2 - 5 } & B. No DMV Match $(\#$ Voters $=196,544)$ \\
\cline { 2 - 5 } Voted & 0.229 & 0.420 & 0 & 1 \\
Hispanic & 0.047 & 0.212 & 0 & 1 \\
Black & 0.390 & 0.488 & 0 & 1 \\
White & 0.504 & 0.500 & 0 & 1 \\
Other Non-White & 0.059 & 0.235 & 0 & 1 \\
Democrat & 0.575 & 0.494 & 0 & 1 \\
Republican & 0.192 & 0.394 & 0 & 1 \\
Unaffiliated & 0.233 & 0.423 & 0 & 1 \\
Birth Year & 1965 & 23 & 1910 & 1999 \\
\hline \hline The & & & 0 & 1 \\
\hline
\end{tabular}

The unit for voted an individual-year. Panel A presents descriptive statistics for the full file of North Carolina voters registered as of the 2014 general election. In this panel, every observation is a voter within an election period. Panel B presents descriptive statistics for the individuals in the voter file who do not match to a DMV identification record.

We also rely on individual-level data from the NCSBE on which voters cast a provisional ballot. Not only can we observe whether a provisional ballot was cast and ultimately counted, but we can also observe the stated reason for needing to cast a provisional ballot. We use this to estimate the mechanical effect of the voter ID law - that is, how many voters are turned away at the polls for lack of ID on Election Day. 


\section{Strict Photo ID Laws Decrease Turnout Among Those Without ID While In Effect}

In this section, we show that North Carolina's voter ID law decreased turnout among those without state ID. In our most stringent specification, the ID law decreased turnout by about 0.7 percentage points among those without ID. This decrease comes both through the differential deterrent effect and through a mechanical effect where voters without ID are turned away at the polls on Election Day. This is consistent with voters who lack identification knowing, based on the letter they received, that they would be turned away at the polls because they lack identification and be unable to vote.

\subsection{Evidence for a Mechanical Effect}

First, we estimate the mechanical effect of the voter ID law, where a voter shows up to the polls intending to cast a ballot but does not have their vote counted because they do not meet the requirements of the new ID law. This mechanical effect can only plausibly decrease the turnout rate (Henninger, Meredith, and Morse 2018; Fraga and Miller 2018), where voters show up to the polls but are challenged to present appropriate ID and fail to do so. ${ }^{13}$ In North Carolina, this mechanical effect is present in the 2016 primary, the only election for which the voter ID law is actually in place. ${ }^{14}$ To estimate the mechanical effect, we subset to provsional ballots that were ultimately rejected, and in Figure 1 we plot the share of provisional ballots cast by reason for each election. ${ }^{15}$ The figure on the left shows provisional ballots for primary elections, while the figure on the right shows them for general elections. In each year, the vast majority of provisional ballots are cast because potential

\footnotetext{
${ }^{13}$ It is also possible that voters produce valid ID at the polls but are inappropriately rejected. For more discussion of how voter ID requirements are applied on Election Day, see Atkeson et al. (2014).

${ }^{14}$ See Appendix section A.3 for a brief discussion of the small number of provisional ballots cast for lack of ID in election before 2016.

${ }^{15}$ For ease of presentation, we show provisional ballots for the two most relevant types of reasons in our study: not being registered and not providing ID. We show a more complete set of provisional ballot reasons in Section A.4 of the Appendix.
} 


\section{Primary Elections}

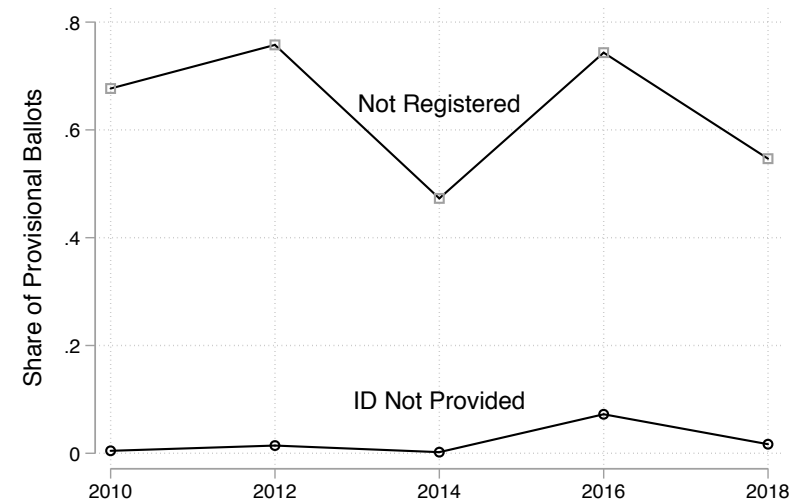

General Elections

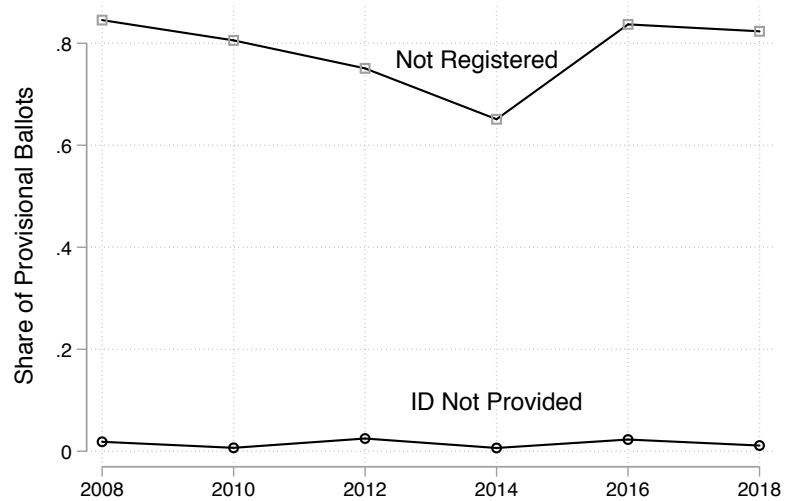

Figure 1 - Reasons for Provisional Ballots The left panel plots the share of provisional ballots cast for different reasons in primary elections. The right plots the same series for general elections. The blue line indicates the share of provisional ballots cast because the voter lacked proper ID. The only election for which the ID law was in effect was the 2016 primary, where about $10 \%$ of provisional ballots were cast for lack of ID.

voters are not found as being registered. Provisional ballots that were rejected for lack of ID account for a very small share of rejected ballots, even in the 2016 primary, where they comprised less than $10 \%$ of rejected ballots. Overall, a total of 1,169 provisional ballots were rejected for lack of ID in the 2016 primary election, approximately $0.05 \%$ of the $2,332,428$ total votes cast statewide in that election.

How many of these provisional ballots rejected for lack of ID come from individuals who do not match to a state ID? In Figure 2 we plot the share of individuals who fail to match to a state ID, first for all registrants on the left and then for provisional balloters on the right. Light grey bars indicate individuals who lack ID, and dark grey bars indicate individuals who have ID. The light grey bar on the right shows that of the 1,169 provisional ballots that were rejected of lack of ID, about $18.2 \%$ of them were identified as lacking ID. This rate of $18.2 \%$ is much higher than the rate among all registrants of $3.0 \%$, meaning the mechanical effect censors out individuals who lack ID at a much higher rate than those who have ID. However, the other $81.8 \%$ of provisional balloters actually linked to a state ID. This suggests 


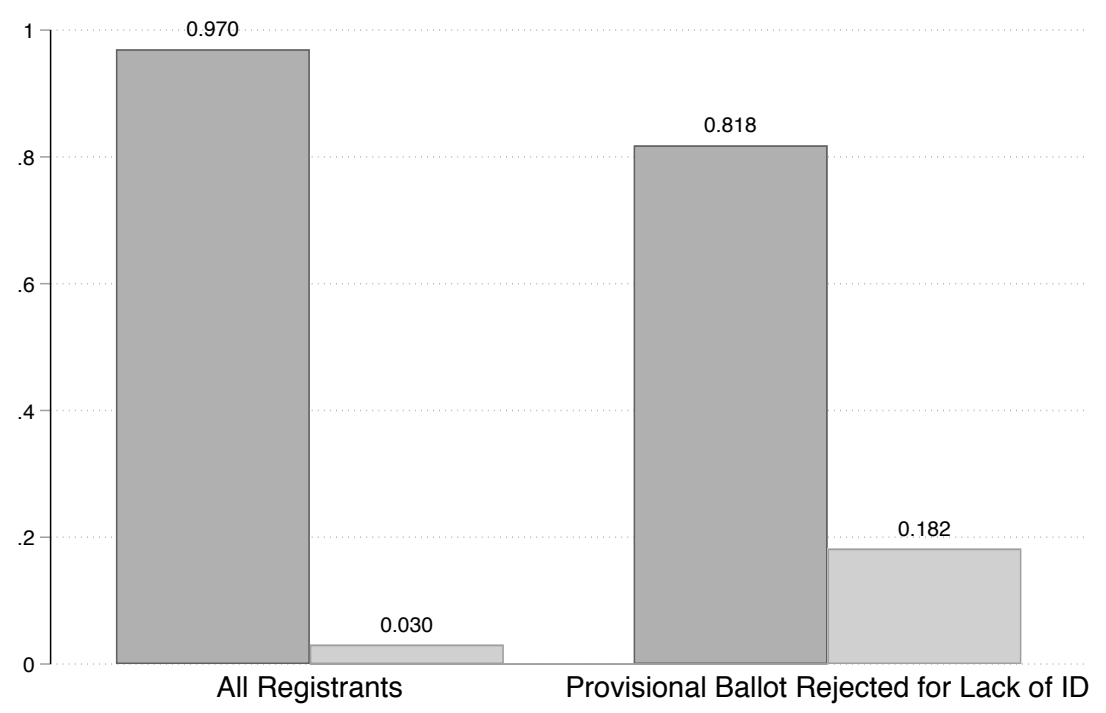

Figure 2 - DMV Match Status: Comparing Registrants to Provisional Balloters The light grey bars indicate individuals who lack ID, while the dark grey bars indicate individuals who match to a DMV-issued ID. We plot these proporotions separately for all registered voters on the left and for those who cast a provisional ballot in the 2016 primary election but had it rejected because they failed to present adequate ID.

that many rejected votes come from individuals who hold a valid ID, likely because they forgot their photo ID on Election Day.

\subsection{Evidence for a Deterrent Effect}

Next, we estimate the deterrent effect of the voter ID law, which yields conflicting theoretical predictions. On one hand, voters without state ID might abstain from voting because they infer - correctly or incorrectly - that they do not have adequate ID to vote and are not willing to pay the costs of acquiring acceptable ID. ${ }^{16}$ On the other hand, the voter ID law might anger or otherwise motivate voters, making them more likely to overcome the law by obtaining valid identification and participate (e.g., Claibourn and Martin 2012; Valentino and Neuner 2017).

\footnotetext{
${ }^{16}$ These costs could include the time it takes to gather information about the law's requirements along with the effort to apply for an acceptable ID.
} 
To estimate the differential deterrent effect of the ID laws we estimate equations of the form

$$
\text { Turnout }_{i t}=\beta * \text { No DMV }_{\text {Match }_{i}} * 2016+\gamma_{i}+\delta_{t}+\epsilon_{i t}
$$

where Turnout $_{i t}$ is an indicator for whether individual $i$ turns out to vote in the election at time $t$. The variable No DMV $\mathrm{Match}_{i} * 2016$ is an indicator for whether individual $i$ does not match to photo ID and the election year is 2016, the year the voter ID law goes into effect. We include individual and year fixed effects, modeled by $\gamma_{i}$ and $\delta_{t}$, respectively. ${ }^{17}$ This is a difference-in-differences design, which relies on the common trends assumption. For this to be satisfied, it must be that the change in turnout behavior for treated units (those without state ID) would have been the same as controls units (those with state ID), had they not been treated. There are likely many differences between those who have a state-issued ID and those who do not, and these differences might drive changes in turnout behavior. Specifically, the main concern for our design is that there are compositional differences between those who have a state ID and those who do not, as we show in Table 1. Voters without state ID are more likely to be Democrats, minorities, not middle-aged, and have low-turnout in prior elections. If trends in turnout behavior are different on the basis of any of these compositional differences, this would bias the estimate in Equation (1). After showing results from the simplest version of the difference-in-differences design, we employ a number of strategies to adjust for these compositional differences and make the common trends assumption more plausible.

Table 2 shows the effect of the voter ID law on primary election turnout. In column 1, we estimate Equation (1), simply including individual and year fixed effects. This specification, therefore, estimates the counterfactual turnout trends for those without ID using all voters with ID. The estimate suggests that the voter ID law caused a 7.8 percentage point decline in primary election turnout among those without ID relative to those with ID. We have reason

\footnotetext{
${ }^{17}$ The equation does not include No DMV $\mathrm{Match}_{i}$ because it is absorbed by the individual fixed effects.
} 
Table 2 - Effect of Voter ID Law on Primary Election Turnout Among Those Without ID, Individual Level, 2008-2016.

\begin{tabular}{|c|c|c|c|c|c|c|c|}
\hline & \multicolumn{7}{|c|}{ Voted in Primary (0-1) } \\
\hline & (1) & $(2)$ & (3) & (4) & (5) & (6) & (7) \\
\hline No DMV Match * Year $=2016$ & $\begin{array}{l}-0.078 \\
(0.001)\end{array}$ & $\begin{array}{l}-0.073 \\
(0.001)\end{array}$ & $\begin{array}{l}-0.054 \\
(0.001)\end{array}$ & $\begin{array}{c}-0.048 \\
(0.001)\end{array}$ & $\begin{array}{l}-0.009 \\
(0.001)\end{array}$ & $\begin{array}{l}-0.009 \\
(0.001)\end{array}$ & $\begin{array}{r}-0.007 \\
(0.001)\end{array}$ \\
\hline $\mathrm{N}$ & $33,136,560$ & $33,136,560$ & $33,089,505$ & $33,089,485$ & $33,136,560$ & $33,136,560$ & $33,136,560$ \\
\hline \# Voters & $6,627,312$ & $6,627,312$ & $6,617,901$ & $6,617,897$ & $6,627,312$ & $6,627,312$ & $6,627,312$ \\
\hline Individual FEs & $\mathrm{Y}$ & $\mathrm{Y}$ & $\mathrm{Y}$ & $\mathrm{Y}$ & $\mathrm{N}$ & $\mathrm{N}$ & $\mathrm{N}$ \\
\hline Year FEs & $\mathrm{Y}$ & $\mathrm{N}$ & $\mathrm{N}$ & $\mathrm{N}$ & $\mathrm{Y}$ & $\mathrm{Y}$ & $\mathrm{Y}$ \\
\hline Race by Year FEs & $\mathrm{N}$ & $\mathrm{Y}$ & $\mathrm{N}$ & $\mathrm{N}$ & $\mathrm{N}$ & $\mathrm{N}$ & $\mathrm{N}$ \\
\hline Age by Year FEs & $\mathrm{N}$ & $\mathrm{N}$ & $\mathrm{Y}$ & $\mathrm{N}$ & $\mathrm{N}$ & $\mathrm{N}$ & $\mathrm{N}$ \\
\hline Race by Age by Year FEs & $\mathrm{N}$ & $\mathrm{N}$ & $\mathrm{N}$ & $\mathrm{Y}$ & $\mathrm{N}$ & $\mathrm{N}$ & $\mathrm{N}$ \\
\hline Exact Match on Turnout & $\mathrm{N}$ & $\mathrm{N}$ & $\mathrm{N}$ & $\mathrm{N}$ & $\mathrm{Y}$ & $\mathrm{Y}$ & $\mathrm{Y}$ \\
\hline Exact Match on Race & $\mathrm{N}$ & $\mathrm{N}$ & $\mathrm{N}$ & $\mathrm{N}$ & $\mathrm{N}$ & $\mathrm{Y}$ & $\mathrm{Y}$ \\
\hline Exact Match on Age Bin & $\mathrm{N}$ & $\mathrm{N}$ & $\mathrm{N}$ & $\mathrm{N}$ & $\mathrm{N}$ & $\mathrm{N}$ & $\mathrm{Y}$ \\
\hline
\end{tabular}

Robust standard errors clustered by individual in parentheses. Main effects for No DMV Match and 2016 are absorbed by fixed effects. Exact matching on turnout matches units based on all primary and general elections from 2008-2014. For exact matching on age, we construct a separate age bin for each group of voters who were under 18 for a given set of elections, so the cohort of voters who became newly eligible to participate in 2010, 2012, 2014, and 2016 each have their own age bin. For voters who were eligible for all elections since 2008, we construct age deciles.

to be skeptical of this baseline specification. Because there are many observable differences between those who have photo ID and those who do not, the two groups are likely to have different turnout trends. As a first way to address this, in columns 2, 3, and 4 we include race-by-year, age-by-year, and race-by-age-by-year fixed effects, respectively. This means that in column 4, for example, we compute counterfactual trends for individuals without ID using only voters with ID that are the same age and race. The point estimate in column 4 shrinks substantially to a 4.8 percentage point decline in primary turnout among those without ID.

Trends in turnout behavior, however, still might be different among those with and without ID, even within age and racial group. In fact, we can show some evidence for this: in Figure A.3 in the Appendix we plot the mean turnout rate in each primary and general election from 2008 to 2016 separately for those who have and do not have ID, including race by birth year fixed effects. Even within race and birth year, those who do not have photo ID have slightly different turnout trends in the pre-treatment period (2008-2014) than those who have ID. ${ }^{18}$

\footnotetext{
${ }^{18}$ We also evaluate the parallel trends assumption further in Section A.6 of the Appendix.
} 
To make the common trends assumption more plausible, we exactly match individuals on the basis of their pre-treatment turnout history. This constructs a control group more likely to provide accurate counterfactual trends because we constrain the trends to be the same in the pre-treatment periods. We have pre-treatment turnout history for every voter from every primary and general election in 2008, 2010, 2012, and 2014. This means that we can put each voter into one of $2^{8}=256$ unique pre-treatment turnout histories. For every individual without a state-issued ID, we can find control units with the same pre-treatment turnout history. In column 5 of Table 2, we implement this exact matching design, where we average the differences in 2016 primary turnout among those without ID and those with ID for each of these turnout histories, weighting the estimate by the number of treated observations in each bin. After exact matching voters on their pre-treatment turnout, we find that the voter ID law caused about a 0.9 percentage point decline in turnout among those without ID. For the specifications where we carry out the exact matching, we do not include individual fixed effects. Individual fixed effects are no longer necessary because, within each turnout history bin, there is no difference in turnout between treated and control units in the pre-period. In columns 6 and 7, we further refine the exact match. In column 6 , we exact match on turnout history and race. In column 7, our most stringent specification, we exact match on turnout history, race, and age decile; we find that the voter ID law caused a precisely estimated 0.7 percentage point decrease in turnout among those without ID. ${ }^{19}$

\subsection{Voter File Purges and Sample Selection}

One concern with using voter files for these types of analyses is that their composition changes over time. Voter file purges could bias our estimates of the effect of the voter ID law. For example, if voter ID laws decrease participation among those without ID, and

\footnotetext{
${ }^{19}$ For exact matching on age, we construct a separate age bin for each group of voters who were under 18 for a given set of elections, so the cohort of voters who became newly eligible to participate in 2010, 2012, 2014, and 2016 each have their own age bin. This ensures that we are not mistakenly comparing individuals who did not vote in past elections but were eligible to individuals who would have voted in past elections but did not because they were too young to be eligible.
} 
participation influences a voter's likelihood of being purged from the voter rolls, we would be inducing bias if we were to condition on those who remain in the voter file through 2018 (e.g., Nyhan, Skovron, and Titiunik 2017). For this reason, we limit our sample to those who were registered pre-treatment - those who were registered as of the 2014 general election. This is also the voter file snapshot that the North Carolina State Board of Elections used to match voters to their DMV records, so by limiting our sample to this set of voters, we know that the voter was included in the state's ID matching procedure. We do not include those who newly registered after the 2014 general election in our analysis because they were not included in the state's ID matching, so we do not observe their ID holding status.

Our sample selection presents one source of measurement error in individuals' voting histories. Imagine a voter who newly registers in 2012, for example. We code this as not having voted in all elections prior to their registration. It could be, however, that the voter moved in from out of state and had indeed been voting in another state. In that case, we would incorrectly be coding this voter as not having voted in elections prior to 2012, when in fact they had been. To circumvent this potential source of measurement error, in Section A.7 of the Appendix we estimate the deterrent effect of the ID law, but we limit the sample only to those who were registered to vote in North Carolina prior to 2008. These are voters for which we can be sure that there is no measurement error in their turnout history because

they are registered throughout our entire panel. The deterrent effects of the ID law among these long-time registrants are smaller in magnitude compared to our estimates using the full sample, but they are still negative and substantively meaningful.

\subsection{The Deterrent Effect of the Voter ID Law Persisted Even Af- ter the Law was Overturned}

North Carolina's voter ID law was overturned in July 2016, about three months before the 2016 general election. As a result of the appellate court striking down the law, the mechanical effect necessarily goes to zero. But, as discussed above, voters might incorrectly believe that 
Table 3 - Effect of Voter ID Law on General Election Turnout Among Those Without ID, Individual Level, 2008-2016.

\begin{tabular}{lccccccc}
\hline \hline & & \multicolumn{3}{c}{ Voted in General $(0-1)$} & & $(5)$ & $(6)$ \\
& $(1)$ & $(2)$ & $(3)$ & $(4)$ & $(5)$ & -0.026 \\
No DMV Match * Year = 2016 & -0.119 & -0.122 & -0.106 & -0.101 & -0.032 & -0.031 & -0.026 \\
& $(0.001)$ & $(0.001)$ & $(0.001)$ & $(0.001)$ & $(0.001)$ & $(0.001)$ & $(0.001)$ \\
$\mathrm{N}$ & $33,136,560$ & $33,136,560$ & $33,089,505$ & $33,089,485$ & $33,136,560$ & $33,136,560$ & $33,089,505$ \\
\# Voters & $6,627,312$ & $6,627,312$ & $6,617,901$ & $6,617,897$ & $6,627,312$ & $6,627,312$ & $6,617,901$ \\
Individual FEs & $\mathrm{Y}$ & $\mathrm{Y}$ & $\mathrm{Y}$ & $\mathrm{Y}$ & $\mathrm{N}$ & $\mathrm{N}$ & $\mathrm{N}$ \\
Year FEs & $\mathrm{Y}$ & $\mathrm{N}$ & $\mathrm{N}$ & $\mathrm{N}$ & $\mathrm{Y}$ & $\mathrm{Y}$ & $\mathrm{Y}$ \\
Race by Year FEs & $\mathrm{N}$ & $\mathrm{Y}$ & $\mathrm{N}$ & $\mathrm{N}$ & $\mathrm{N}$ & $\mathrm{N}$ & $\mathrm{N}$ \\
Age by Year FEs & $\mathrm{N}$ & $\mathrm{N}$ & $\mathrm{Y}$ & $\mathrm{N}$ & $\mathrm{N}$ & $\mathrm{N}$ & $\mathrm{N}$ \\
Race by Age by Year FEs & $\mathrm{N}$ & $\mathrm{N}$ & $\mathrm{N}$ & $\mathrm{Y}$ & $\mathrm{N}$ & $\mathrm{N}$ & $\mathrm{N}$ \\
Exact Match on Turnout & $\mathrm{N}$ & $\mathrm{N}$ & $\mathrm{N}$ & $\mathrm{N}$ & $\mathrm{Y}$ & $\mathrm{Y}$ & $\mathrm{Y}$ \\
Exact Match on Race & $\mathrm{N}$ & $\mathrm{N}$ & $\mathrm{N}$ & $\mathrm{N}$ & $\mathrm{N}$ & $\mathrm{Y}$ & $\mathrm{Y}$ \\
Exact Match on Age Bin & $\mathrm{N}$ & $\mathrm{N}$ & $\mathrm{N}$ & $\mathrm{N}$ & $\mathrm{N}$ & $\mathrm{N}$ & $\mathrm{Y}$ \\
\hline \hline
\end{tabular}

Robust standard errors clustered by individual in parentheses. Main effects for No DMV Match and 2016 are absorbed by fixed effects. Exact matching on turnout matches units based on each primary and general election from the 2008 primary through the 2014 general. For exact matching on age, we construct a separate age bin for each group of voters who were under 18 for a given set of elections, so the cohort of voters who became newly eligible to participate in 2010, 2012, 2014, and 2016 each have their own age bin. For voters who were eligible for all elections since 2008, we construct age deciles.

an ID is still required to vote in the general election, resulting in the law still exerting a differential deterrent effect on voting on individuals without identification.

To investigate this differential deterrent effect, in Table 3 we estimate the effect on turnout of not having ID for the 2016 general election. Each column mirrors the specification described in Table 2, except that the outcome is now voting in the general election. For brevity, we focus on our most stringent specification (column 7), where we use exact matching on turnout history, race, and age.

In this most stringent specification, we find that voters without a state ID were 2.6 percentage points less likely to vote in the 2016 general compared to individuals with a state ID. The deterrent effect of the law persisted after the law was struck down and the effect of the law increased in size. This increase, however, reflects the higher participation rate in general rather than primary elections. In 2016, for example, $36 \%$ of registered voters participated in the primary election, while $69 \%$ participated in the general election. Therefore, this increase in size reflects the higher baseline rate of vote propensity in North Carolina elections.

To assess how the differential effect persists, we estimate the effect of not holding identification on turnout in the 2018 primary (Table 4) and the 2018 general election (Table 5). 
Table 4 - Effect of Voter ID Law on Primary Election Turnout Among Those Without ID, Individual Level, 2008-2018.

\begin{tabular}{|c|c|c|c|c|c|c|c|}
\hline & \multicolumn{7}{|c|}{ Voted in Primary $(0-1)$} \\
\hline & (1) & $(2)$ & (3) & (4) & (5) & (6) & $(7)$ \\
\hline No DMV Match * Year $\geq 2016$ & $\begin{array}{c}-0.078 \\
(0.001)\end{array}$ & $\begin{array}{c}-0.073 \\
(0.001)\end{array}$ & $\begin{array}{l}-0.054 \\
(0.001)\end{array}$ & $\begin{array}{r}-0.048 \\
(0.001)\end{array}$ & & & \\
\hline No DMV Match * Year $\geq 2018$ & $\begin{array}{c}0.102 \\
(0.001)\end{array}$ & $\begin{array}{c}0.087 \\
(0.001)\end{array}$ & $\begin{array}{c}0.088 \\
(0.001)\end{array}$ & $\begin{array}{c}0.077 \\
(0.001)\end{array}$ & $\begin{array}{l}-0.003 \\
(0.001)\end{array}$ & $\begin{array}{c}-0.003 \\
(0.001)\end{array}$ & $\begin{array}{r}-0.001 \\
(0.001)\end{array}$ \\
\hline $\mathrm{N}$ & $39,763,872$ & $39,763,872$ & $39,707,406$ & $39,707,382$ & $33,136,560$ & $33,136,560$ & $33,089,505$ \\
\hline \# Voters & $6,627,312$ & $6,627,312$ & $6,617,901$ & $6,617,897$ & $6,627,312$ & $6,627,312$ & $6,617,901$ \\
\hline Individual FEs & $\mathrm{Y}$ & $\mathrm{Y}$ & $\mathrm{Y}$ & $\mathrm{Y}$ & $\mathrm{N}$ & $\mathrm{N}$ & $\mathrm{N}$ \\
\hline Year FEs & $\mathrm{Y}$ & $\mathrm{N}$ & $\mathrm{N}$ & $\mathrm{N}$ & $\mathrm{Y}$ & $\mathrm{Y}$ & $\mathrm{Y}$ \\
\hline Race by Year FEs & $\mathrm{N}$ & $\mathrm{Y}$ & $\mathrm{N}$ & $\mathrm{N}$ & $\mathrm{N}$ & $\mathrm{N}$ & $\mathrm{N}$ \\
\hline Age by Year FEs & $\mathrm{N}$ & $\mathrm{N}$ & $\mathrm{Y}$ & $\mathrm{N}$ & $\mathrm{N}$ & $\mathrm{N}$ & $\mathrm{N}$ \\
\hline Race by Age by Year FEs & $\mathrm{N}$ & $\mathrm{N}$ & $\mathrm{N}$ & $\mathrm{Y}$ & $\mathrm{N}$ & $\mathrm{N}$ & $\mathrm{N}$ \\
\hline Exact Match on Turnout & $\mathrm{N}$ & $\mathrm{N}$ & $\mathrm{N}$ & $\mathrm{N}$ & $\mathrm{Y}$ & $\mathrm{Y}$ & $\mathrm{Y}$ \\
\hline Exact Match on Race & $\mathrm{N}$ & $\mathrm{N}$ & $\mathrm{N}$ & $\mathrm{N}$ & $\mathrm{N}$ & $\mathrm{Y}$ & $\mathrm{Y}$ \\
\hline Exact Match on Age Bin & $\mathrm{N}$ & $\mathrm{N}$ & $\mathrm{N}$ & $\mathrm{N}$ & $\mathrm{N}$ & $\mathrm{N}$ & $\mathrm{Y}$ \\
\hline
\end{tabular}

Robust standard errors clustered by individual in parentheses. Main effects for No DMV Match and 2016 are absorbed by fixed effects. Exact matching on turnout matches units based on each primary and general election from the 2008 primary through the 2014 general. For exact matching on age, we construct a separate age bin for each group of voters who were under 18 for a given set of elections, so the cohort of voters who became newly eligible to participate in 2010, 2012, 2014, and 2016 each have their own age bin. For voters who were eligible for all elections since 2008, we construct age deciles.

Again, focusing on our most stringent specification (Column 7 in both tables) we find that there was essentially no differential effect in the 2018 primary election - with those without identification only 0.1 percentage point less likely to turnout. But in the 2018 general election, those without identification were 1.7 percentage points less likely to vote. This $35 \%$ reduction in magnitude compared to the effect in the 2016 general election is consistent with voters' confusion about what is necessary to vote dissipating, but the smaller effect in 2018 could also simply reflect lower rates of turnout in midterm elections. ${ }^{20}$

\subsection{Interpretation of The Voter ID Law's Effect}

Interpreting these results requires caution. We estimate the differential deterrent effect, which is not estimating how overall turnout change in North Carolina as a result of the voter ID law. Instead, it is the differential effect on turnout for those without a state-issued

\footnotetext{
${ }^{20}$ Another explanation for the persistent deterrent effect of the ID law could be habit disruption. Even if voters are not confused about the ID law's requirements, it could be that because they were prevented from voting in the 2016 primary, their "habit" of voting was disrupted, causing them to be less likely to turn out in future elections (e.g. Brody and Sniderman 1977; Gerber, Green, and Shachar 2003).
} 
Table 5 - Effect of Voter ID Law on General Election Turnout Among Those Without ID, Individual Level, 2008-2018.

\begin{tabular}{|c|c|c|c|c|c|c|c|}
\hline & \multicolumn{7}{|c|}{ Voted in General (0-1) } \\
\hline & (1) & $(2)$ & $(3)$ & (4) & $(5)$ & $(6)$ & $(7)$ \\
\hline No DMV Match * Year $\geq 2016$ & $\begin{array}{c}-0.119 \\
(0.001)\end{array}$ & $\begin{array}{l}-0.122 \\
(0.001)\end{array}$ & $\begin{array}{l}-0.106 \\
(0.001)\end{array}$ & $\begin{array}{r}-0.101 \\
(0.001)\end{array}$ & & & \\
\hline No DMV Match * Year $\geq 2018$ & $\begin{array}{c}0.048 \\
(0.001)\end{array}$ & $\begin{array}{c}0.049 \\
(0.001)\end{array}$ & $\begin{array}{c}0.060 \\
(0.001)\end{array}$ & $\begin{array}{c}0.060 \\
(0.001)\end{array}$ & $\begin{array}{l}-0.024 \\
(0.001)\end{array}$ & $\begin{array}{c}-0.023 \\
(0.001)\end{array}$ & $\begin{array}{r}-0.017 \\
(0.001)\end{array}$ \\
\hline $\mathrm{N}$ & $39,763,872$ & $39,763,872$ & $39,707,406$ & $39,707,382$ & $33,136,560$ & $33,136,560$ & $33,089,505$ \\
\hline \# Voters & $6,627,312$ & $6,627,312$ & $6,617,901$ & $6,617,897$ & $6,627,312$ & $6,627,312$ & $6,617,901$ \\
\hline Individual FEs & $\mathrm{Y}$ & $\mathrm{Y}$ & $\mathrm{Y}$ & $\mathrm{Y}$ & $\mathrm{N}$ & $\mathrm{N}$ & $\mathrm{N}$ \\
\hline Year FEs & $\mathrm{Y}$ & $\mathrm{N}$ & $\mathrm{N}$ & $\mathrm{N}$ & $\mathrm{Y}$ & $\mathrm{Y}$ & $\mathrm{Y}$ \\
\hline Race by Year FEs & $\mathrm{N}$ & $\mathrm{Y}$ & $\mathrm{N}$ & $\mathrm{N}$ & $\mathrm{N}$ & $\mathrm{N}$ & $\mathrm{N}$ \\
\hline Age by Year FEs & $\mathrm{N}$ & $\mathrm{N}$ & $\mathrm{Y}$ & $\mathrm{N}$ & $\mathrm{N}$ & $\mathrm{N}$ & $\mathrm{N}$ \\
\hline Race by Age by Year FEs & $\mathrm{N}$ & $\mathrm{N}$ & $\mathrm{N}$ & $\mathrm{Y}$ & $\mathrm{N}$ & $\mathrm{N}$ & $\mathrm{N}$ \\
\hline Exact Match on Turnout & $\mathrm{N}$ & $\mathrm{N}$ & $\mathrm{N}$ & $\mathrm{N}$ & $\mathrm{Y}$ & $\mathrm{Y}$ & $\mathrm{Y}$ \\
\hline Exact Match on Race & $\mathrm{N}$ & $\mathrm{N}$ & $\mathrm{N}$ & $\mathrm{N}$ & $\mathrm{N}$ & $\mathrm{Y}$ & $\mathrm{Y}$ \\
\hline Exact Match on Age Bin & $\mathrm{N}$ & $\mathrm{N}$ & $\mathrm{N}$ & $\mathrm{N}$ & $\mathrm{N}$ & $\mathrm{N}$ & $\mathrm{Y}$ \\
\hline
\end{tabular}

Robust standard errors clustered by individual in parentheses. Main effects for No DMV Match and 2016 are absorbed by fixed effects. Exact matching on turnout matches units based on each primary and general election from the 2008 primary through the 2014 general. For exact matching on age, we construct a separate age bin for each group of voters who were under 18 for a given set of elections, so the cohort of voters who became newly eligible to participate in 2010, 2012, 2014, and 2016 each have their own age bin. For voters who were eligible for all elections since 2008, we construct age deciles.

ID relative to those with a state-issued ID. It is possible that the voter ID law could have depressed turnout among all voters, regardless of ID holding status, if voters that did have ID were also confused about the new requirements to vote. Alternatively, it could be that the voter ID law increased overall turnout among all voters if they were angered or otherwise motivated to vote because of the new requirements (e.g., Valentino and Neuner 2017). The quantity we estimate captures the effect of the ID law on turnout among those without ID relative to those with ID. We believe that, given the compositional differences between the types of voters with and without ID, this theoretical quantity is interesting and important. Later, we estimate the effect of the voter ID law on overall turnout in North Carolina. To do so, we use our estimated mechanical effects for individuals with and without valid ID as well as our differential deterrent effect; but calculating the overall effect of the law on turnout requires an additional assumption that the law has no deterrent effect among those who have ID, an effect not identified by our design. 


\section{Who is Deterred by the ID Law?}

In this section, we evaluate which types of voters are most likely to be deterred by the voter ID law. We find that not holding identification has the biggest effect for occasional voters, with only small effects for voters who rarely turned out in prior elections or who participated in all prior elections. We also find that the effect of the voter ID law does not vary substantially by race or by party, but this does not imply that there is not a disproportionate burden for minorities or democrats. Although the effect of not holding identification does not differ from members of different racial groups or partisans, voter ID laws do disproportionately burden Democrats and racial minorities because they are less likely to hold photo identification (see Table 1).

\subsection{Voter ID Laws Mostly Deter Occasional Voters}

To examine how the effect varies based on turnout history, we construct strata of treated and control units based on the total number of times a voter casted a ballot in primary and general elections before the law was implemented. The strata that we use for this analysis are similar to the strata we use in our exact matching design, except for ease of presentation we merely count the number of primary and general elections an individual had participated in previously, rather than differentiating based on which primary or general elections the individual had participated in. In Table A.5 we estimate the difference in primary turnout among those without ID and those with ID in the 2016 primary election in each of the turnout strata and in Table A.6 we estimate the difference in each strata, but for general election turnout.

For brevity, we do not review the estimation procedure here, but instead do so in detail in Section A.8 of the Appendix. But, to summarize, we show the voter ID law did not seem to deter low propensity or high propensity voters without state-issued ID relative to those with 
ID. Instead, the voter law deterred voters without ID who participated only occasionally before the law went into effect.

\subsection{The Effect of the Law Does Not Vary by Race or Party, But There Is Still a Deterrent Effect for Minorities and Democrats}

Perhaps one of the most important legal questions about voter ID laws is assessing whether the laws impose a disproportionate burden on racial minorities. And as a public policy question, it is important to know whether the laws change the partisan composition of the election. To make this evaluation, we need to combine information about the rate groups hold valid identification for voting and how the effect of the law varies by group.

We first test for whether the effect of not holding valid identification varies depending on an individuals race and party affiliation. For brevity, we focus only on the effect in the 2016 general election, but we show the results for the 2016 primary election in Section A.9 of the Appendix. Table 6 shows the effect of the voter ID law on general election turnout by race. We interact the treatment variable, not holding valid identification, with indicators for whether the voter is listed as Black, Hispanic, and Other Non-White in the voter file. In our most stringent exact matching specification in column 7 , we do not find evidence that the effect of the voter ID law on those without ID varies substantially by race, with individuals from all racial groups deterred by the law.

We also investigate whether the effect of the voter ID law varies by party registration. Table A.9 shows that in our preferred specification, the effect of the voter ID law does not vary substantially by party registration.

Critically, the lack of heterogeneous effects does not imply that the voter ID laws did not affect the composition of the electorate or that they did not disproportionately deter minorities. In fact, combining the results of this analysis and the information in Table 1 suggests that minority voters and Democrats are disproportionately deterred from voting. Because minority voters are less likely to hold the required identification to vote, the homogeneous 
Table 6 - Effect of Voter ID Law on General Election Turnout Among Those Without ID, Individual Level, 2008-2016.

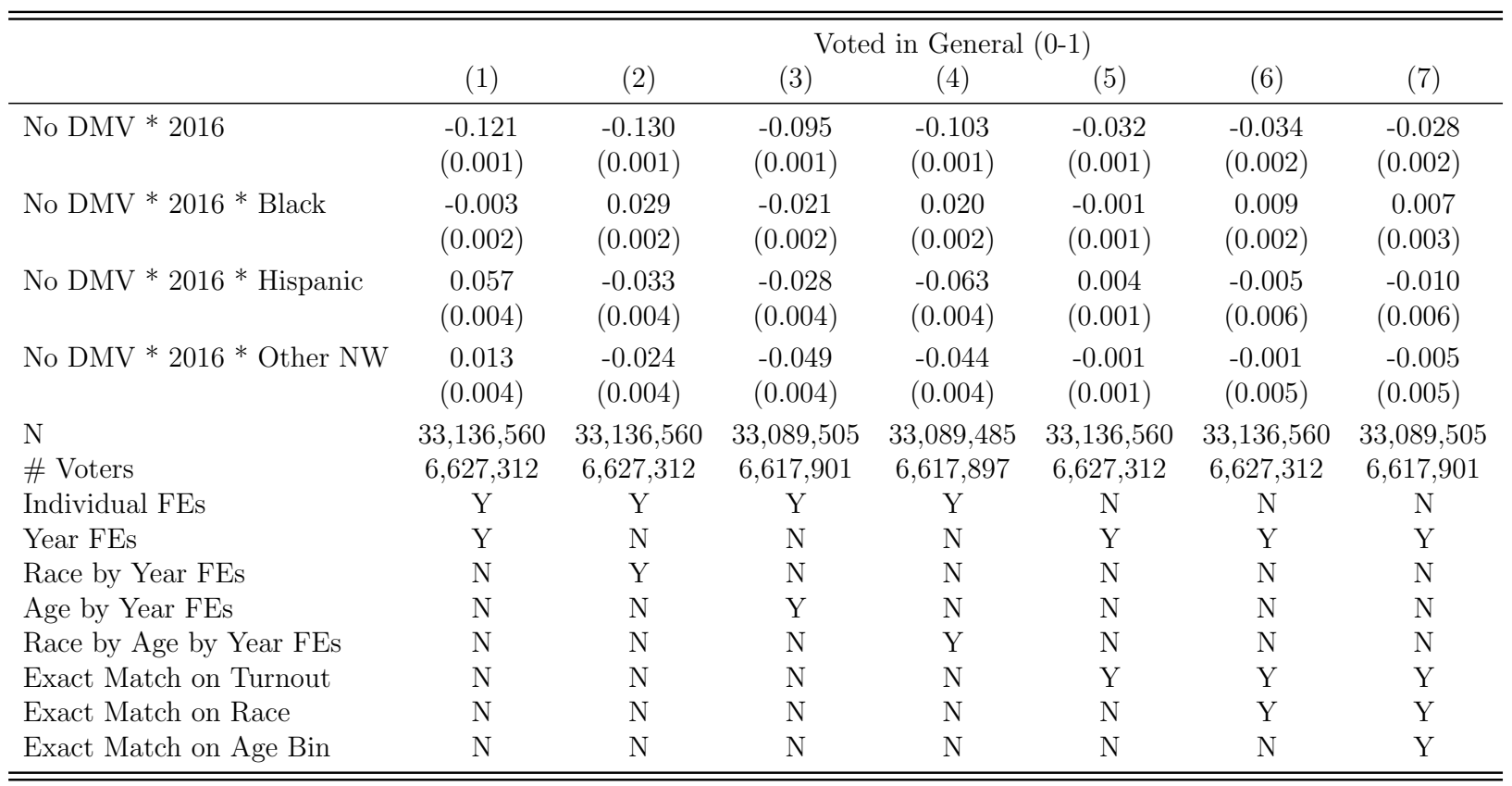

Robust standard errors clustered by individual in parentheses. Main effects for No DMV Match and 2016 are absorbed by fixed effects. Exact matching on turnout matches units based on all primary and general elections from the 2008 primary through the 2014 general. For exact matching on age, we construct a separate age bin for each group of voters who were under 18 for a given set of elections, so the cohort of voters who became newly eligible to participate in 2010, 2012, 2014, and 2016 each have their own age bin. For voters who were eligible for all elections since 2008, we construct age deciles.

effects implies that minority voters were less likely to participate in the 2016 primary and general elections as the result of the law. Similarly, because registered Democrats were less likely to hold valid identification they were disproportionately deterred. We demonstrate this directly in the next section, showing how many voters were deterred and how this altered the composition of the electorate.

\section{Characterizing the Overall Effect of the ID Law}

Here, we incorporate our findings so far along with the composition of voters with and without ID to try to answer three questions about the effect of the voter ID law in North Carolina. First, what effect did the law have on overall turnout? Second, what was the total reduction in overall turnout by race and by party affiliation? Third, how did the voter ID law change the racial and partisan composition of the electorate? 
To answer the first question, we define the overall effect as the following:

$$
\text { Overall Effect }=\text { Mechanical Effect }+ \text { Deterrent Effect }
$$

where the mechanical effect is given by the number of provisional ballots that were ultimately rejected for lack of adequate photo ID, and the deterrent effect is given by the following equation:

Deterrent Effect $=($ Deterrent Effect $\mid$ No ID $) *(\#$ No ID $)+($ Deterrent Effect $\mid$ ID $) *(\#$ ID $)$

The deterrent effect among those who have photo ID is not identified using our research design. Our estimates in this section, therefore, assume this quantity to be equal to zero. ${ }^{21}$ We compute the probability of not holding ID simply as the share of registrants that do not match to a DMV record (3.0\%), and we compute the deterrent effect using the point estimates from our most stringent specifications (column 7) in Tables 2 and 3 for the primary and general elections, respectively. The overall effect of the voter ID law on primary election turnout in number of votes, therefore, is

Overall Effect in Primary $=$ Mechanical Effect in Primary + Deterrent Effect in Primary

$$
\begin{aligned}
& =-1,169-(0.007) * 196,544 \\
& \approx-1,169-1,376 \\
& =-2,545
\end{aligned}
$$

which is about $0.116 \%$ of the 2016 primary electorate in North Carolina. This is consistent with Cantoni and Pons (2019), which finds small effects of voter ID laws on overall turnout

\footnotetext{
${ }^{21}$ Substantively, this would mean that the implementation of the voter ID law had no effect on turnout among those who have photo ID. This could be violated in a few ways. First, those with photo ID might nonetheless be confused by the law and be deterred from voting. Second, those with photo ID might be motivated by the ID law, either because they are angry that those without ID could be disenfranchised, or because they are less costly for parties and interest groups to mobilize.
} 
using a nationwide voter file panel. Even in a large nationwide panel researchers lack the power to detect this sized effect. Similarly, the overall effect in the general election is

$$
\begin{aligned}
\text { Overall Effect in General } & =\underbrace{\text { Mechanical Effect in General }}_{0}+\text { Deterrent Effect in General } \\
& =0-(0.026) * 196,544 \\
& \approx-5,110
\end{aligned}
$$

which is about $0.122 \%$ of the 2016 general electorate in North Carolina. ${ }^{22}$

Reconciling Null and Deterrent Effects These findings help reconcile two competing claims that can both be true. First, prior research has shown that strict voter ID laws cause a decline in turnout among those without photo ID. And second, strict photo ID laws do not cause substantively large declines in overall turnout resulting in null effects for many aggregate level analyses. Our results show that because the vast majority of potential voters hold valid identification, the effect of the voter ID law is to deter only a small number of voters. In an aggregate setting this number of voters is sufficiently small that there is no design, to our knowledge, with sufficient power to detect the effect on this small number of voters.

\subsection{How Voter ID Laws Change the Composition of the Electorate}

We perform similar calculations to assess how voter ID laws affect partisan and racial composition of the electorate. To do this, we decompose overall turnout effects by race and by party using the following procedure. For the mechanical effect in the 2016 primary election, we simply sum the number of voters who had provisional ballots ultimately rejected for lack of ID for each racial group and for each party affiliation. For the deterrent effect, we multiply our estimated deterrent effect (from column 7 of Tables 2 and 3, respectively) among

\footnotetext{
${ }^{22}$ The mechanical effect in the 2016 general election is equal to zero because the strict photo ID law was not in effect for this election.
} 
those without ID by the total number of voters without ID who belong to each racial group and partisan affiliation. ${ }^{23}$ Adding the mechanical effect and the deterrent effect gives an estimate of the overall vote reduction, which we summarize in Table 7. Panel A decomposes the vote reduction by race, and Panel B decomposes the vote reduction by party affiliation. For example, we estimate that in the 2016 primary election the strict photo ID law reduced turnout among White voters by about 1,342 votes, 648 of which came through a mechanical effect and 694 of which came through a deterrent effect. We also show the overall effect as a fraction of the total number of voters in that group who lack ID, and as a fraction of the total number of registrants in that group. For example, the overall vote reduction of 1,342 votes in the 2016 primary among Whites represents about $1.3 \%$ of the total number of White voters without an ID, and it represents $0.03 \%$ of the total number of White registrants.

Reporting the effect as the share of registrants in that group makes the disproportionate effect of the law by race and by party clear. Looking at the 2016 general election, for example, $0.06 \%$ of registered White voters were deterred by the ID law, while $0.13 \%$ of registered Black voters were deterred by the law. This illustrates how the voter ID law can have disproportionate effects on turnout by race. Black registrants are much more likely to lack ID than White registrants, so they bear a larger burden of the turnout reduction even though the size of the effect among those without ID is not larger for Black voters than for White voters.

In Panel $\mathrm{B}$ we decompose the vote reduction by party affiliation. We find that the ID law reduced turnout among Democrats by about 1,461 votes, 670 of which came from a mechanical effect and 791 of which came from a deterrent effect. As a share of the total vote reduction, Democratic registrants account for about $57.4 \%$ of the total vote reduction in the 2016 primary and about $57.5 \%$ of the reduction in the 2016 general election.

\footnotetext{
${ }^{23}$ This assumes that the effect of the voter ID law among those without ID is constant across race and across party. We find in Tables 6 and A.9 that the effects do not seem to vary substantially by these characteristics.
} 
Table 7 - Vote Reduction from Voter ID Law by Race and Party Affiliation

\begin{tabular}{|c|c|c|c|c|c|c|c|c|}
\hline & \multicolumn{8}{|c|}{ A. Decomposition by Race } \\
\hline & \multicolumn{5}{|c|}{2016 Primary } & \multicolumn{3}{|c|}{2016 General } \\
\hline & Mech. & Det. & Overall & $\begin{array}{l}\text { Effect as \% o } \\
\text { Grp. w/o ID }\end{array}$ & $\begin{array}{l}\text { Effect as \% of } \\
\text { Grp. Reg. }\end{array}$ & Overall & $\begin{array}{l}\text { Effect as \% of } \\
\text { Grp. w/o ID }\end{array}$ & $\begin{array}{c}\text { Effect as \% of } \\
\text { Grp. Reg. }\end{array}$ \\
\hline White & 648 & 694 & 1,342 & $1.3 \%$ & $0.03 \%$ & 2,577 & $2.8 \%$ & $0.06 \%$ \\
\hline Black & 421 & 536 & 957 & $1.2 \%$ & $0.06 \%$ & 1,993 & $2.1 \%$ & $0.13 \%$ \\
\hline Hispanic & 22 & 65 & 87 & $0.9 \%$ & $0.07 \%$ & 241 & $3.8 \%$ & $0.18 \%$ \\
\hline Other Non-White & 78 & 81 & 159 & $1.4 \%$ & $0.07 \%$ & 299 & $3.3 \%$ & $0.13 \%$ \\
\hline Total & 1,169 & 1,376 & 2,545 & $1.3 \%$ & $0.04 \%$ & 5,110 & $2.6 \%$ & $0.08 \%$ \\
\hline
\end{tabular}

\begin{tabular}{|c|c|c|c|c|c|c|c|c|}
\hline & \multicolumn{8}{|c|}{ B. Decomposition by Party } \\
\hline & \multicolumn{5}{|c|}{2016 Primary } & \multicolumn{3}{|c|}{2016 General } \\
\hline & Mech. & Det. & Overall & $\begin{array}{l}\text { Effect as } \% \text { of } \\
\text { Grp. w/o ID }\end{array}$ & $\begin{array}{c}\text { Effect as \% of } \\
\text { Grp. Reg. }\end{array}$ & Overall & $\begin{array}{l}\text { Effect as \% of } \\
\text { Grp. w/o ID }\end{array}$ & $\begin{array}{c}\text { Effect as \% of } \\
\text { Grp. Reg. }\end{array}$ \\
\hline Democrat & 670 & 791 & 1,461 & $1.3 \%$ & $0.05 \%$ & 2,936 & $2.6 \%$ & $0.11 \%$ \\
\hline Republican & 265 & 264 & 529 & $1.4 \%$ & $0.03 \%$ & 982 & $2.8 \%$ & $0.05 \%$ \\
\hline Unaffiliated & 234 & 321 & 555 & $1.2 \%$ & $0.03 \%$ & 1,192 & $2.5 \%$ & $0.07 \%$ \\
\hline Total & 1,169 & 1,376 & 2,545 & $1.3 \%$ & $0.04 \%$ & 5,110 & $2.6 \%$ & $0.08 \%$ \\
\hline
\end{tabular}

Note: Each cell presents an estimated total reduction in turnout as a consequence of the voter ID law. Panel A decomposes the effect of the voter ID law by racial group. Panel B decomposes the effect of the voter ID law by party affiliation. The first five columns decompose the effect in the 2016 primary, while the last three columns decompose the effect in the 2016 general. "Mech" represents the mechanical effect, and "Det" represents the deterrent effect. Effect as \% of Grp. w/o ID is the overall effect for the group divided by the total number of voters without ID in that group. Effect as \% of Grp. Reg. is the overall effect for the group divided by the total number of registered voters in that group. Note that the mechanical effect is zero in the 2016 general election because the law was not in effect for that election, so the deterrent effect is the same as the overall effect.

We can see that the size of the effect as a percentage of voters in that group without an ID does not vary substantially by party $-2.6 \%$ and $2.8 \%$ of Democrats without ID and Republicans without ID, respectively, did not vote because of the ID law in the 2016 general election. But because Democrats are much more likely to lack ID than are Republicans, Democrats shoulder a disproportionate share of the overall vote reduction as a share of total registrants. $0.11 \%$ of registered Democrats did not vote in the 2016 general election because of the ID law, while only $0.05 \%$ of Republicans did not vote in the 2016 general because of the ID law.

To situate the vote reductions due to the voter ID law in a broader context, in Table A.10 in the Appendix we add the vote reductions from Table 7 - that is, the number of additional voters we estimate would have participated had the law not been passed - to the observed number of voters in each election. It shows that, because the effects among those without 
ID are relatively small, along with the fact that those without ID make up a small portion of the electorate, these vote reductions have only a small effect on the overall composition of the electorate, at least along racial and partisan dimensions. We reiterate, that this interpretation of the findings requires relatively strong assumptions about voter behavior in the absence of the law. Specifically, that the law had no effect on the participation decision of those with the required identification. ${ }^{24}$

\section{Conclusion}

Voter ID laws are politically contentious, with Republican legislatures often implementing strict requirements, and these laws are occasionally softened or overturned as a result of legal challenges (Hicks et al. 2015). How these laws affect voter turnout is an important question, but there is little empirical work on the effects of these laws that uses administrative data on individual turnout over time along with a measure of which individuals actually might lack ID. And no studies have considered how the effect of the laws could remain even after the law is repealed. We leverage information in North Carolina on which voters lack photo ID to estimate the effect of North Carolina's voter ID law on turnout among those identified as possibly lacking photo ID and how the extent to which the law's effects remained in place even after an appellate court struck down the law. We find that the North Carolina voter ID law deterred voters both in the primary and general election and that this occurred both because the law mechanically made individuals unable to vote because they lacked the required identification and because the law exerted a general deterrent effect as voters inferred they would be unable to vote and therefore declined to turnout at all.

These findings also help reconcile two seemingly disparate findings in the voter ID literature, but which we argue need not be mutually exclusive, because they are estimating two different quantities of interest. The first quantity of interest is the differential effect of

\footnotetext{
${ }^{24}$ We could assess the sensitivity of this assumption by making assumptions about how the size of the effect among those with ID compares to the effect size among those without ID.
} 
voter ID laws on turnout among those without ID. Our findings - along with other recent work that combines individual-level information on who actually lacks ID in Rhode Island, measured at scale (Esposito, Focanti, and Hastings 2019) - show that voter ID laws cause a differential decrease in turnout among those without ID, leaving minorities and Democrats disproportionately burdened because they are less likely to have photo ID. The second quantity of interest is the effect of voter ID laws on overall turnout, including both individuals with and without identification. Using our estimates of differential turnout and plausible assumptions about the effect of the law on those with identification, we find that the effects of voter ID laws on overall turnout are very small because very few voters lack photo ID. This is consistent with recent work using a nationwide voter file panel (Cantoni and Pons 2019). Both of these theoretical quantities are important, and our work furthers our understanding on both of these fronts. Moreover, this paper illustrates that the widely varying findings in the voter ID literature stem from the combination of lack of clarity about which is the estimand of interest along with limited data and to estimate either of these quantities with precision.

Our results also suggest important policy considerations as states consider voter identification laws and then those laws are contested in courts. If voters are not informed about changing laws they may continue to be deterred by the incorrect belief that they lack proper identification to vote. Future research should examine effective ways to inform voters about the changing requirements to cast ballots. 


\section{References}

Alvarez, R Michael, Delia Bailey, and Jonathan N Katz. 2008. The Effect of Voter Identification Laws on Turnout. Technical Report 1267R California Institute of Technology Social Science Working Paper Series.

Alvarez, R Michael, Delia Bailey, and Jonathan N Katz. 2011. "An Empirical Bayes Approach to Estimating Ordinal Treatment Effects." Political Analysis 19(1): 20-31.

Ansolabehere, Stephen. 2012. Report on Racial Differences in Matching Voter Registration Lists to Driver's License and License to Carry Databases in the State of Texas. Technical report Paper Submitted in Texas v. Holder, June 30, No. 12-0128 (D.D.C.).

Ansolabehere, Stephen, and Eitan D Hersh. 2017. "ADGN: An Algorithm for Record Linkage Using Address, Date of Birth, Gender, and Name." Statistics and Public Policy 4(1): 1-10.

Atkeson, Lonna Rae, Yann P Kerevel, R Michael Alvarez, and Thad E Hall. 2014. "Who Asks for Voter Identification? Explaining Poll-Worker Discretion." Journal of Politics 76(4): 944-957.

Barreto, Matt A.; Gabriel R. Sanchez, and Hannah Walker. 2012. Rates of Possession of Valid Photo identification, and Public Knowledge of the Voter ID Law in Pennsylvania. Technical report Paper Submitted in Applewhite v. Commonwealth, July 16, No. 330 MD 2012 (Pa. Commw. Ct.).

Barreto, Matt A, Stephen A Nuño, and Gabriel R Sanchez. 2009. "The Disproportionate Impact of Voter ID Requirements on the Electorate: New Evidence from Indiana." PS: Political Science 8 Politics 42(01): 111-116.

Beatty, Leland. 2012. Technical report Declaration Submitted in League of United Latin American Citizens v. Deininger, April 23, No. 12-00185 (E.D. Wis.). 
Brody, Richard A, and Paul M Sniderman. 1977. "From life space to polling place: The relevance of personal concerns for voting behavior." British Journal of Political Science 7(3): 337-360.

Cantoni, Enrico, and Vincent Pons. 2019. "Strict ID Laws Don't Stop Voters: Evidence from a US Nationwide Panel, 2008-2016." National Bureau of Economic Research Working Paper No. 25522.

Claibourn, Michele P, and Paul S Martin. 2012. "Creating Constituencies: Presidential Campaigns, the Scope of Conflict, and Selective Mobilization." Political Behavior 34(1): $27-56$.

Erikson, Robert S, and Lorraine C Minnite. 2009. "Modeling Problems in the Voter Identification-Voter Turnout Debate." Election Law Journal 8(2): 85-101.

Esposito, Francesco Maria, Diego Focanti, and Justine S Hastings. 2019. "Effects of Photo ID Laws on Registration and Turnout: Evidence from Rhode Island." National Bureau of Economic Research Working Paper No. 25503.

Fraga, Bernard, and Michael Miller. 2018. "Who Does Voter ID Keep From Voting?".

Gerber, Alan S, Donald P Green, and Ron Shachar. 2003. "Voting may be habit-forming: evidence from a randomized field experiment." American Journal of Political Science 47(3): $540-550$.

Grimmer, Justin, Eitan Hersh, Marc Meredith, Jonathan Mummolo, and Clayton Nall. 2018. "Obstacles to Estimating Voter ID Laws' Effect on Turnout." The Journal of Politics 80(3): $1045-1051$.

Hajnal, Zoltan, Nazita Lajevardi, and Lindsay Nielson. 2017. "Voter Identification Laws and the Suppression of Minority Votes." The Journal of Politics 79(2): 000-000. 
Henninger, Phoebe, Marc Meredith, and Michael Morse. 2018. "Who Votes Without Identification? Using Affidavits from Michigan to Learn About the Potential Impact of Strict Photo Voter Identification Laws.".

Hicks, William D, Seth C McKee, Mitchell D Sellers, and Daniel A Smith. 2015. "A Principle or a Strategy? Voter Identification Laws and Partisan Competition in the American States." Political Research Quarterly 68(1): 18-33.

Highton, Benjamin. 2017. "Voter Identification Laws and Turnout in the United States." Annual Review of Political Science 20: 149-167.

Hobby, Bill, Cong Huang, David Llanos, Chris Mainka, Kwok-Wai Wan, Ching-Hsing Wang, and Isaiah Warner. 2015. "The Texas Voter ID Law and the 2014 Election: A Study of Texas's 23rd Congressional District.".

Hood, MV, and Charles S Bullock. 2008. "Worth a Thousand Words? An Analysis of Georgia's Voter Identification Statute." American Politics Research 36(4): 555-579.

Hood, MV, and Charles S Bullock. 2012. "Much Ado About Nothing? An Empirical Assessment of the Georgia Voter Identification Statute." State Politics 83 Policy Quarterly 12(4): 394-414.

Hopkins, Daniel J, Marc Meredith, Michael Morse, Sarah Smith, and Jesse Yoder. 2017. "Voting But For the Law: Evidence from Virginia on Photo Identification Requirements." Journal of Empirical Legal Studies 14(1): 79-128.

Mycoff, Jason D, Michael W Wagner, and David C Wilson. 2009. "The Empirical Effects of Eoter-ID Laws: Present or absent?" PS: Political Science $\mathcal{E}$ Politics 42(01): 121-126.

Nyhan, Brendan, Christopher Skovron, and Rocío Titiunik. 2017. "Differential Registration Bias in Voter File Data: A Sensitivity Analysis Approach." American Journal of Political Science 61(3): 744-760. 
Stewart III, Charles. 2013. "Voter ID: Who Has Them; Who Shows Them." Okla. L. Rev. 66: 21 .

Valentino, Nicholas A, and Fabian G Neuner. 2017. "Why the Sky Didn't Fall: Mobilizing Anger in Response to Voter ID Laws." Political Psychology 38(2): 331-350. 


\section{Online Appendix}

Intended for online publication only.

\section{Contents}

A.1 News Coverage of the Voter Identification Law . . . . . . . . . . . . . 2

A.2 Measuring Who Holds Identification . . . . . . . . . . . . . . 3

A.3 Provisional Ballots Cast for Lack of ID in North Carolina . . . . . . . . . . 5

A.4 Reasons for Provisional Ballots . . . . . . . . . . . . . . . . 6

A.5 Turnout by ID Holding Status, Controlling for Birth Year and Race . . . . . 7

A.6 Evaluating the Parallel Trends Assumption . . . . . . . . . . . . . . 8

A.7 Effect of ID Law for Those Registered Pre-2008 . . . . . . . . . . . . . . . . 10

A.8 Effect of Voter ID Law, by Pre-Treatment Turnout . . . . . . . . . . . . . 12

A.9 Exploring Heterogeneity in the Effect by Race and Party Registration . . . 15

A.10 Effect of ID Law on Composition of Electorate . . . . . . . . . . . . . 17 


\section{A.1 News Coverage of the Voter Identification Law}

In order to provide a baseline assessment of how the North Carolina voter identification law was covered, we engage in a simple analysis of newspaper coverage. To do this, we use two different kinds of news sources. To approximate coverage in North Carolina, we use the relatively small paper: The Star News, in Wilmington. And to approximate what national coverage looks like, we used The New York Times, Washington Post, and USA Today. Using the papers we first searched for all stories that contained the words "campaign" and "North Carolina".

From this set of stories we did a simple regular expression search for instances of "voter id". This will capture a variety of uses of the word. Obviously, this might include stories other than those about the requirements for voting or the controversy surrounding the law, but a reading of the stories suggests that this captures stories that cover the North Carolina law.

Figure A.1 counts the number of stories covered in the Star News (left-histogram) and the national papers (right-histogram). We have labeled the date of the appellate court ruling and the date of the election. This shows that a large share of the coverage comes right as the appellate court decision was made, three months before the election. And subsequently there was little coverage in the local paper, even as election day approached. The national papers covered voter identification more, but those stories tended to not focus on the specific requirements in North Carolina.

Figure A.1 - News Coverage of North Carolina Voter ID Law
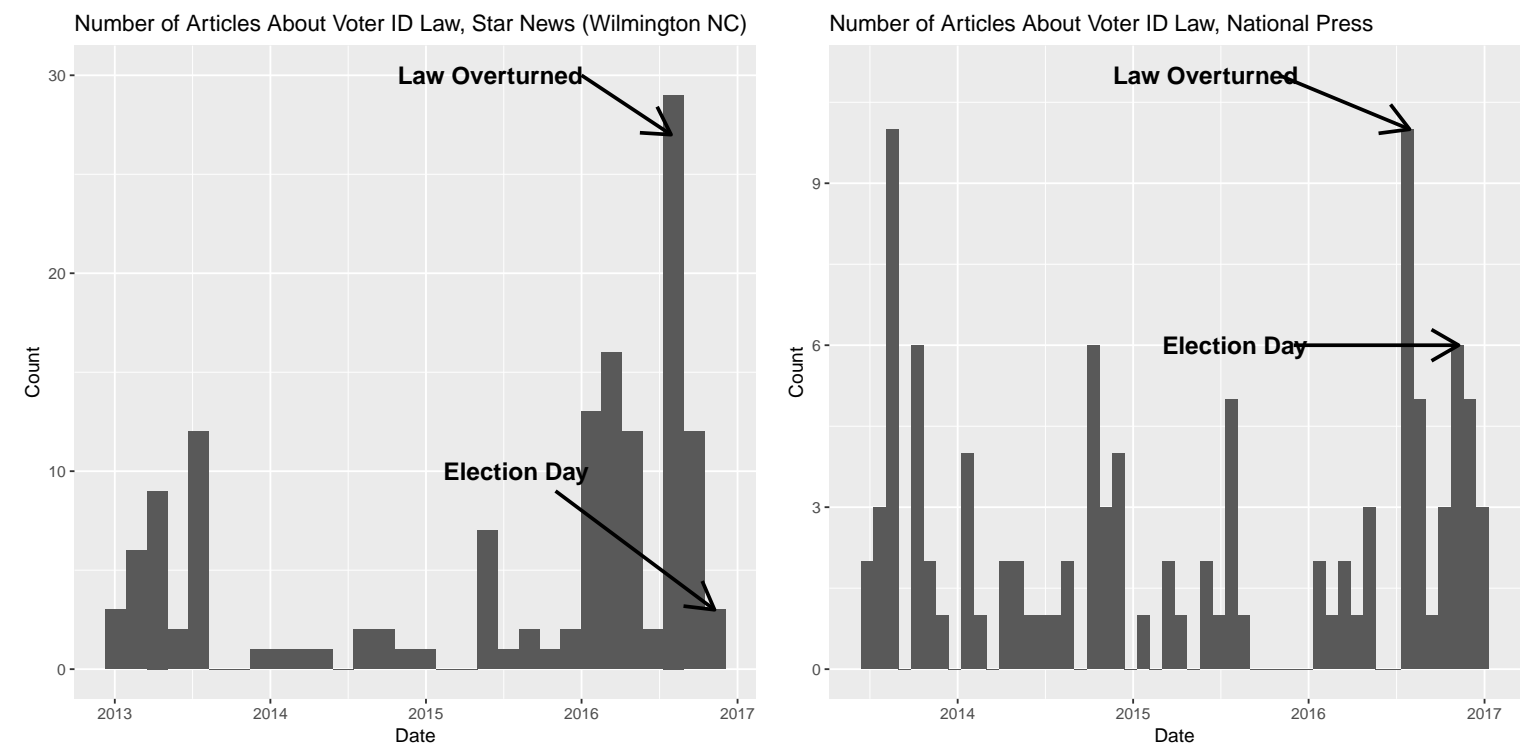

Together, Figure A.1 suggests that voters without identification would not find easily accessible information about the changing requirements for voting. Voters could seek the information out, but it does not appear that the information would happened to be discovered by voters not explicitly looking for the information. 


\section{A.2 Measuring Who Holds Identification}

To measure who lacks a state-issued ID, we combine administrative data from North Carolina voter files - which includes information on a voter's address, age, race, and turnout history in every primary and general election from 2008 to 2016 - with individual-level administrative data on who possesses a state-issued ID. ${ }^{25}$ We use the unique identifier the NCSBE generated to identify voters without identification, which we use to merge to the voter file to measure an individual's lack of ID.

Several features of the matching process suggest the measurement error in this matching is likely to be small. The main source of measurement error comes from matching voters to DMV records. There could be either false positives, where two records are linked but correspond to different individuals, or false negatives, where individuals are not linked but are present in both datasets. Individuals are nearly always unique within characteristics available in the voter file (Ansolabehere and Hersh 2017), which makes the risk of false positives extremely low when merging across these types of administrative data. We have reason to believe the rate of false positives is extremely low in our case: in North Carolina the voter registration records and DMV ID records both contain driver's license or state ID numbers, as well as the last 4 digits of the social security number, date of birth, first name, last name, and full address. ${ }^{26}$ The NCSBE used exact matching on first and last name, as well as either driver's license number or last four digits of social security number, in the vast majority of its matches, making the risk of false positives low. False negatives would come from missingness or typographical errors in variables used for matching, but we again have reason to believe the false negative rate is low. Over $80 \%$ of voter file registrants report their DMV-issued ID number, and individuals report the last 4 digits of their social security number on both the voter registration form and DMV-issued ID forms. Overall, given the quantity and quality of identifying information in both the voter file and the DMV ID records, we suspect that the measurement error in our treatment variable is likely to be small.

Even if the matching process had no merge error, people who possess ID might lack access to it on Election Day (Henninger, Meredith, and Morse 2018). For example, voters could show up to the polls but have lost or forgotten their photo ID. In that case, we would underestimate the number of individuals without photo ID. To the extent that this happens on Election Day, it would attenuate our estimates of the effect of the voter ID law among those without ID because individuals in our control group (coded as having ID) would be deterred. It is also possible that some individuals without state-issued ID could still have photo ID required to vote, such as a US passport or valid military ID. In that case, voters with acceptable ID would be coded as treated, leading us to over-estimate the number of voters who actually lack acceptable photo ID. We can measure this indirectly because the North Carolina State Board of Elections sent a mailer to each voter that did not match to state ID records. For registrants on the state's no match list, about $8.6 \%$ responded to the

\footnotetext{
${ }^{25}$ All of this information is publicly available and provided by the North Carolina State Board of Elections (NCSBE).

${ }^{26}$ The NCSBE implemented the same matching criteria as described in this report: https://canons.sog. unc.edu/wp-content/uploads/2013/12/St-Bd-voter-ID-report.pdf
} 
NCSBE mailer claiming they had photo ID. ${ }^{27}$ This would also attenuate an estimate of the differential effect of law among those who actually lack ID. For these reasons, we interpret our treatment effect as the differential deterrent effect of the voter ID law among those who the state identified as possibly lacking ID, relative to those who have a state ID.

$\overline{27}$ https://www.ncmd.uscourts.gov/sites/ncmd/files/opinions/13cv658moo_0.pdf. 


\section{A.3 Provisional Ballots Cast for Lack of ID in North Carolina}

In the 2016 primary election, 1,169 provisional ballots were ultimately not counted with the reason listed being that adequate ID was not provided by the voter. For the 2010, 2012, and 2014 primary elections, these counts were 7, 134, and 3, respectively. There are a few possible reasons for non-zero values when the law was not in effect. First, the reason for the provisional ballot could be misreported. Second, by federal statute voters who register by mail and have not yet voted in an election in the state have pending eligibility and are required to provide "current and valid photo identification" or "a current utility bill, bank statement, government check, paycheck, or other government document that shows the name and address of the voter." (https://uscode.house.gov/view . xhtml?path=\&req=\%28title\%3A52+section $\%$ 3A21083+edition\%3Aprelim\%29\&f=\&f $q=\& n u m=0 \& h l=f a l$ se\&edition=prelim). Third, poll workers - who exercise considerable discretion - might inappropriately ask voters to present ID in these elections. For example, over one-third of New Mexico poll workers indicated they had asked voters that approached without ID to present photo identification during the 2008 general election, contrary to New Mexico election law (Atkeson et al. 2014). 


\section{A.4 Reasons for Provisional Ballots}

In this section, we show the share of provisional ballots cast by reason for each election. Figure A.2 shows provisional ballot reasons for primary elections on the left and general elections on the right. The y-axis represents the share of provisional ballots cast in the election for each type of reason. As discussed in the main text, the vast majority of rejected provisional ballots are because the voter was not registered, and this is true for every election in our study. Other reasons for provisional ballots include voting at the incorrect precinct, voting the wrong party's ballot in the primary, or having been previously removed from the voter file, among others.

\section{Primary Elections}

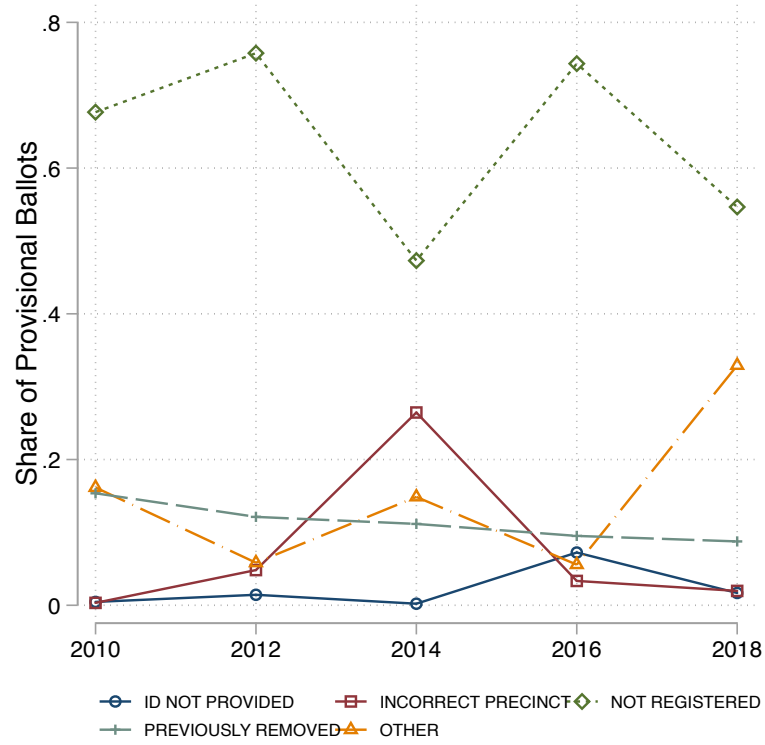

\section{General Elections}

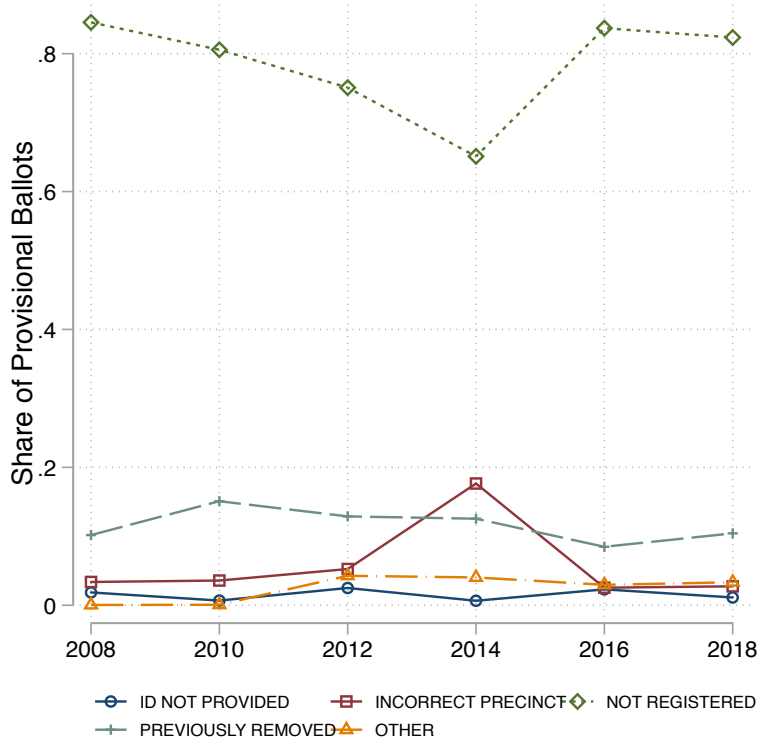

Figure A.2 - Reasons for Provisional Ballots The left panel plots the share of provisional ballots cast for different reasons in primary elections. The right plots the same series for general elections. The blue line indicates the share of provisional ballots cast because the voter lacked proper ID. The only election for which the ID law was in effect was the 2016 primary, where about $10 \%$ of provisional ballots were cast for lack of ID. 


\section{A.5 Turnout by ID Holding Status, Controlling for Birth Year and Race}

In this section, we plot the mean turnout rate in each primary and general election from 2008 to 2016 separately for those who have and do not have ID, including race by birth year fixed effects. Even within race and birth year, those who do not have photo ID (in red) have slightly different turnout trends in the pre-treatment period (2008-2014) than those who have ID (in blue).

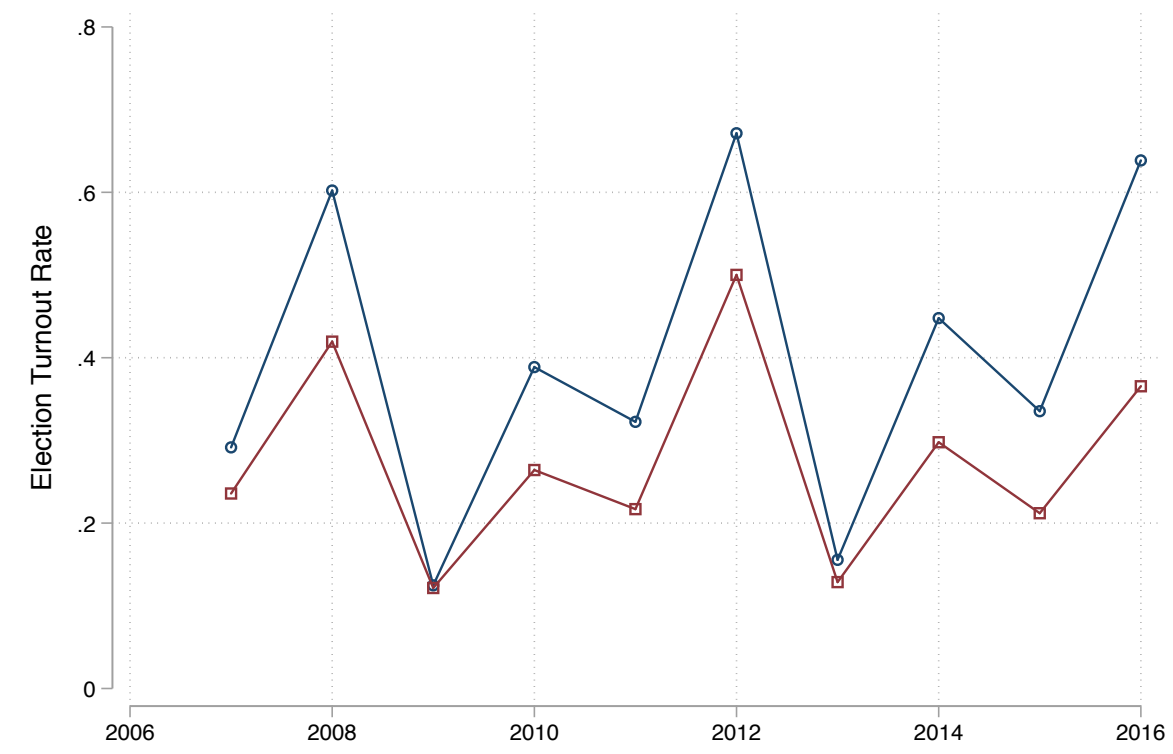

Figure A.3 - Turnout by ID Holding Status, Controlling for Birth

Year and Race. Mean election turnout for primary and general elections from 2008 through 2016 are plotted separately for those who do not match to a DMVissued ID record (in red squares) and for those who do match to a photo ID (in blue circles). We residualize on race by birth year fixed effects, so the figure shows that trends in turnout among these two groups are different in the pre-treatment periods (2008-2014) even after controlling for race and birth year. 


\section{A.6 Evaluating the Parallel Trends Assumption}

Our estimation of the deterrent effect of the voter ID law on turnout among those without ID, in Tables 2 and 3, relies on the parallel trends assumption being satisfied. In column 1 of these tables, where we simply include individual fixed effects and year fixed effects, it must be the case that individuals who lacked ID would have followed the same turnout trends in 2016 as those who had ID. There are reasons to be skeptical of this assumption, given that there are large differences between the types of people who have photo ID and those who do not. For that reason, in columns 2 through 7 of Tables 2 and 3 we adjust the estimation in a variety of ways to make the parallel trends assumption increasingly plausible. We describe these alternative specifications in more detail in the main body of the paper, but in this section we try to assess whether the parallel trends assumption might be satisfied under each of our specifications.

Table A.1 - Evidence of Pre-Trending: Effect of Voter ID Law Lead on Primary Election Turnout Among Those Without ID, Individual Level, 2008-2016.

\begin{tabular}{|c|c|c|c|c|c|c|c|}
\hline & \multicolumn{7}{|c|}{ Voted in Primary $(0-1)$} \\
\hline & (1) & $(2)$ & $(3)$ & (4) & $(5)$ & (6) & (7) \\
\hline No DMV Match $*$ Year $=2016$ & $\begin{array}{c}-0.071 \\
(0.001)\end{array}$ & $\begin{array}{l}-0.067 \\
(0.001)\end{array}$ & $\begin{array}{l}-0.048 \\
(0.001)\end{array}$ & $\begin{array}{c}-0.042 \\
(0.001)\end{array}$ & & & \\
\hline No DMV Match $*$ Year $=2014$ & $\begin{array}{c}0.026 \\
(0.001)\end{array}$ & $\begin{array}{c}0.023 \\
(0.001)\end{array}$ & $\begin{array}{c}0.023 \\
(0.001)\end{array}$ & $\begin{array}{c}0.023 \\
(0.001)\end{array}$ & $\begin{array}{l}-0.003 \\
(0.001)\end{array}$ & $\begin{array}{c}-0.003 \\
(0.001)\end{array}$ & $\begin{array}{r}-0.004 \\
(0.001)\end{array}$ \\
\hline $\mathrm{N}$ & $33,136,560$ & $33,136,560$ & $33,089,505$ & $33,089,485$ & $26,509,248$ & $26,509,248$ & $26,471,604$ \\
\hline \# Voters & $6,627,312$ & $6,627,312$ & $6,617,901$ & $6,617,897$ & $6,627,312$ & $6,627,312$ & $6,617,901$ \\
\hline Individual FEs & $\mathrm{Y}$ & $\mathrm{Y}$ & $\mathrm{Y}$ & $\mathrm{Y}$ & $\mathrm{N}$ & $\mathrm{N}$ & $\mathrm{N}$ \\
\hline Year FEs & Yes & $\mathrm{N}$ & $\mathrm{N}$ & $\mathrm{N}$ & $\mathrm{Y}$ & $\mathrm{Y}$ & $\mathrm{Y}$ \\
\hline Race by Year FEs & $\mathrm{N}$ & $\mathrm{Y}$ & $\mathrm{N}$ & $\mathrm{N}$ & $\mathrm{N}$ & $\mathrm{N}$ & $\mathrm{N}$ \\
\hline Age by Year FEs & $\mathrm{N}$ & $\mathrm{N}$ & $\mathrm{Y}$ & $\mathrm{N}$ & $\mathrm{N}$ & $\mathrm{N}$ & $\mathrm{N}$ \\
\hline Race by Age by Year FEs & $\mathrm{N}$ & $\mathrm{N}$ & $\mathrm{N}$ & $\mathrm{Y}$ & $\mathrm{N}$ & $\mathrm{N}$ & $\mathrm{N}$ \\
\hline Exact Match on Turnout & $\mathrm{N}$ & $\mathrm{N}$ & $\mathrm{N}$ & $\mathrm{N}$ & $\mathrm{Y}$ & $\mathrm{Y}$ & $\mathrm{Y}$ \\
\hline Exact Match on Race & $\mathrm{N}$ & $\mathrm{N}$ & $\mathrm{N}$ & $\mathrm{N}$ & $\mathrm{N}$ & $\mathrm{Y}$ & $\mathrm{Y}$ \\
\hline Exact Match on Age Bin & $\mathrm{N}$ & $\mathrm{N}$ & $\mathrm{N}$ & $\mathrm{N}$ & $\mathrm{N}$ & $\mathrm{N}$ & $\mathrm{Y}$ \\
\hline
\end{tabular}

To do so, in Table A.1 we mirror the columns in Table 2 but include a lead of the treatment variable to check for evidence of pre-trending. We find that the coefficients on the leads are small, and the coefficients on the main effects in columns 1-4 remain similar to those in Table 2. This adds to the plausibility of the parallel trends assumption, at least for primary election turnout.

In columns 5-7, because we use exact matching on pre-treatment turnout, we have to adjust the estimation slightly to check for pre-trending. We implement exact matching on 2008-2012 primary and general election turnout, and then we estimate the effect of the voter ID law among those without ID in 2014, which is before the voter ID law went into effect. We see substantively small, but negative, effects on these coefficients, suggesting that turnout 
among those without ID declined slightly prior to the law being implemented, even after matching exactly on turnout history, race, and age decile. One possible explanation for this is that the North Carolina voter ID law was passed in 2013 but to be implemented starting in 2016. If individuals without ID were confused about when the law went into effect, they could have been deterred from voting even prior to the law being implemented.

\section{Table A.2 - Evidence of Pre-Trending: Effect of Voter ID Law Lead on General Election Turnout Among Those Without ID, Individual Level, 2008-2016.}

\begin{tabular}{|c|c|c|c|c|c|c|c|}
\hline & \multicolumn{7}{|c|}{ Voted in General (0-1) } \\
\hline & (1) & $(2)$ & (3) & (4) & $(5)$ & (6) & (7) \\
\hline No DMV Match $*$ Year $=2016$ & $\begin{array}{c}-0.117 \\
(0.001)\end{array}$ & $\begin{array}{l}-0.120 \\
(0.001)\end{array}$ & $\begin{array}{c}-0.105 \\
(0.001)\end{array}$ & $\begin{array}{c}-0.099 \\
(0.001)\end{array}$ & & & \\
\hline No DMV Match $*$ Year $=2014$ & $\begin{array}{c}0.008 \\
(0.001)\end{array}$ & $\begin{array}{c}0.009 \\
(0.001)\end{array}$ & $\begin{array}{c}0.006 \\
(0.001)\end{array}$ & $\begin{array}{c}0.009 \\
(0.001)\end{array}$ & $\begin{array}{l}-0.011 \\
(0.001)\end{array}$ & $\begin{array}{c}-0.010 \\
(0.001)\end{array}$ & $\begin{array}{r}-0.009 \\
(0.001)\end{array}$ \\
\hline $\mathrm{N}$ & $33,136,560$ & $33,136,560$ & $33,089,505$ & $33,089,485$ & $26,509,248$ & $6,627,312$ & $26,509,248$ \\
\hline \# Voters & $6,627,312$ & $6,627,312$ & $6,617,901$ & $6,617,897$ & $6,627,312$ & $26,509,248$ & $6,627,312$ \\
\hline Individual FEs & $\mathrm{Y}$ & $\mathrm{Y}$ & $\mathrm{Y}$ & $\mathrm{Y}$ & $\mathrm{N}$ & $\mathrm{N}$ & $\mathrm{N}$ \\
\hline Year FEs & $\mathrm{Y}$ & $\mathrm{N}$ & $\mathrm{N}$ & $\mathrm{N}$ & $\mathrm{Y}$ & $\mathrm{Y}$ & $\mathrm{Y}$ \\
\hline Race by Year FEs & $\mathrm{N}$ & $\mathrm{Y}$ & $\mathrm{N}$ & $\mathrm{N}$ & $\mathrm{N}$ & $\mathrm{N}$ & $\mathrm{N}$ \\
\hline Age by Year FEs & $\mathrm{N}$ & $\mathrm{N}$ & $\mathrm{Y}$ & $\mathrm{N}$ & $\mathrm{N}$ & $\mathrm{N}$ & $\mathrm{N}$ \\
\hline Race by Age by Year FEs & $\mathrm{N}$ & $\mathrm{N}$ & $\mathrm{N}$ & $\mathrm{Y}$ & $\mathrm{N}$ & $\mathrm{N}$ & $\mathrm{N}$ \\
\hline Exact Match on Turnout & $\mathrm{N}$ & $\mathrm{N}$ & $\mathrm{N}$ & $\mathrm{N}$ & $\mathrm{Y}$ & $\mathrm{Y}$ & $\mathrm{Y}$ \\
\hline Exact Match on Race & $\mathrm{N}$ & $\mathrm{N}$ & $\mathrm{N}$ & $\mathrm{N}$ & $\mathrm{N}$ & $\mathrm{Y}$ & $\mathrm{Y}$ \\
\hline Exact Match on Age Bin & $\mathrm{N}$ & $\mathrm{N}$ & $\mathrm{N}$ & $\mathrm{N}$ & $\mathrm{N}$ & $\mathrm{N}$ & $\mathrm{Y}$ \\
\hline
\end{tabular}

Next, in Table A.2 we do the same checks for pre-trending using general election turnout as the outcome. Here, the results are similar: using our exact matching approach in columns 5-7, those who did not match to a DMV record saw a small decline in turnout in 2014, before the voter ID law went into effect. Again, this is consistent with the idea that if individuals were confused about the timing of the law's implementation, the deterrent effects of the voter ID law on those without ID could manifest prior to the law going into effect. 


\section{A.7 Effect of ID Law for Those Registered Pre-2008}

In this section, we estimate the deterrent effect of the ID law, but we limit the sample to those registered before 2008, the start of our panel. In the main results in Table 2, the sample is all registrants as of the 2014 general election, which is the voter file the North Carolina State Board of Elections used to match voters to DMV records. This means that in our main analyses, we face one small measurement issue: for voters who registered sometime between 2008 and 2014, we cannot be sure of their true turnout history. Imagine a voter who newly registers in 2012, for example. We code this as not having voted in all elections prior to their registration. It could be, however, that the voter moved in from out of state and had indeed been voting in another state. In that case, we would incorrectly be coding this voter as not having voted in elections prior to 2012, when in fact they had been.

To circumvent this potential source of measurement error, in Table A.3 we estimate the deterrent effect of the ID law in the 2016 primary, but we limit the sample only to those who were registered to vote in North Carolina prior to 2008. This means that we can be sure that there is no measurement error in the voter's turnout history. The tradeoff we make here, however, is that our sample in Table A.3 includes only long-time registrants. We might expect that the effect of the ID law on turnout among those without ID will be different for long-time registrants compared to the full sample we study in the main analyses.

We show the results for the 2016 primary in Table A.3, and the columns mirror those in Table 2 in the main text. In our most preferred specification (column 7), the ID law leads to a decrease in 2016 primary turnout of about 0.5 percentage points among those without ID relative to those with ID. This effect is slightly smaller in magnitude than the one we estimate in 2, which suggests that the effect of the ID law is much smaller among long-time registrants.

Table A.3 - Effect of Voter ID Law on Primary Election Turnout Among Those Without ID, Individual Level, 2008-2016, Including Only Those Registered Pre-2008.

\begin{tabular}{lccccccc}
\hline \hline & \multicolumn{7}{c}{ Voted in Primary $(0-1)$} \\
& $(1)$ & $(2)$ & $(3)$ & $(4)$ & $(5)$ & $(6)$ & $(7)$ \\
\hline No DMV Match * Year $=2016$ & -0.091 & -0.086 & -0.044 & -0.039 & -0.010 & -0.009 & -0.005 \\
& $(0.001)$ & $(0.001)$ & $(0.001)$ & $(0.001)$ & $(0.002)$ & $(0.002)$ & $(0.002)$ \\
N & $19,836,570$ & $19,836,570$ & $19,790,245$ & $19,790,190$ & $19,836,570$ & $19,836,570$ & $19,836,570$ \\
\# Voters & $3,967,314$ & $3,967,314$ & $3,958,049$ & $3,958,038$ & $3,967,314$ & $3,967,314$ & $3,967,314$ \\
Individual FEs & $\mathrm{Y}$ & $\mathrm{Y}$ & $\mathrm{Y}$ & $\mathrm{Y}$ & $\mathrm{N}$ & $\mathrm{N}$ & $\mathrm{N}$ \\
Year FEs & $\mathrm{Y}$ & $\mathrm{N}$ & $\mathrm{N}$ & $\mathrm{N}$ & $\mathrm{Y}$ & $\mathrm{Y}$ & $\mathrm{Y}$ \\
Race by Year FEs & $\mathrm{N}$ & $\mathrm{Y}$ & $\mathrm{N}$ & $\mathrm{N}$ & $\mathrm{N}$ & $\mathrm{N}$ & $\mathrm{N}$ \\
Age by Year FEs & $\mathrm{N}$ & $\mathrm{N}$ & $\mathrm{Y}$ & $\mathrm{N}$ & $\mathrm{N}$ & $\mathrm{N}$ & $\mathrm{N}$ \\
Race by Age by Year FEs & $\mathrm{N}$ & $\mathrm{N}$ & $\mathrm{N}$ & $\mathrm{Y}$ & $\mathrm{N}$ & $\mathrm{N}$ & $\mathrm{N}$ \\
Exact Match on Turnout & $\mathrm{N}$ & $\mathrm{N}$ & $\mathrm{N}$ & $\mathrm{N}$ & $\mathrm{Y}$ & $\mathrm{Y}$ & $\mathrm{Y}$ \\
Exact Match on Race & $\mathrm{N}$ & $\mathrm{N}$ & $\mathrm{N}$ & $\mathrm{N}$ & $\mathrm{N}$ & $\mathrm{Y}$ & $\mathrm{Y}$ \\
Exact Match on Age Bin & $\mathrm{N}$ & $\mathrm{N}$ & $\mathrm{N}$ & $\mathrm{N}$ & $\mathrm{N}$ & $\mathrm{N}$ & $\mathrm{Y}$ \\
\hline \hline
\end{tabular}

Robust standard errors clustered by individual in parentheses. Main effects for No DMV Match and 2016 are absorbed by fixed effects. Exact matching on turnout matches units based on all primary and general elections from 2008-2014. For exact matching on age, we construct a separate age bin for each group of voters who were under 18 for a given set of elections, so the cohort of voters who became newly eligible to participate in 2010,2012, 2014, and 2016 each have their own age bin. For voters who were eligible for all elections since 2008, we construct age deciles. 
We observe the same pattern in for the 2016 general election. We show the results in Table A.4, and the columns mirror those in Table 3. The effect of the ID law on turnout in the 2016 general election about a 1 percentage point decrease when we limit the sample only to long-time registrants, which is much smaller than the 2.6 percentage point decrease we observe in Table 3 when we use the full sample.

Table A.4 - Effect of Voter ID Law on General Election Turnout Among Those Without ID, Individual Level, 2008-2016, Including Only Those Registered Pre-2008.

\begin{tabular}{|c|c|c|c|c|c|c|c|}
\hline & \multicolumn{7}{|c|}{ Voted in General (0-1) } \\
\hline & (1) & $(2)$ & (3) & $(4)$ & (5) & (6) & $(7)$ \\
\hline No DMV Match * Year $=2016$ & $\begin{array}{l}-0.099 \\
(0.001)\end{array}$ & $\begin{array}{l}-0.097 \\
(0.001)\end{array}$ & $\begin{array}{l}-0.032 \\
(0.001)\end{array}$ & $\begin{array}{l}-0.030 \\
(0.001)\end{array}$ & $\begin{array}{l}-0.020 \\
(0.001)\end{array}$ & $\begin{array}{l}-0.019 \\
(0.001)\end{array}$ & $\begin{array}{r}-0.010 \\
(0.002)\end{array}$ \\
\hline $\mathrm{N}$ & $19,836,570$ & $19,836,570$ & $19,790,245$ & $19,790,190$ & $19,836,570$ & $19,836,570$ & $19,790,245$ \\
\hline \# Voters & $3,967,314$ & $3,967,314$ & $3,958,049$ & $3,958,038$ & $3,967,314$ & $3,967,314$ & $3,958,049$ \\
\hline Individual FEs & $\mathrm{Y}$ & $\mathrm{Y}$ & $\mathrm{Y}$ & $\mathrm{Y}$ & $\mathrm{N}$ & $\mathrm{N}$ & $\mathrm{N}$ \\
\hline Year FEs & $\mathrm{Y}$ & $\mathrm{N}$ & $\mathrm{N}$ & $\mathrm{N}$ & $\mathrm{Y}$ & $\mathrm{Y}$ & $\mathrm{Y}$ \\
\hline Race by Year FEs & $\mathrm{N}$ & $\mathrm{Y}$ & $\mathrm{N}$ & $\mathrm{N}$ & $\mathrm{N}$ & $\mathrm{N}$ & $\mathrm{N}$ \\
\hline Age by Year FEs & $\mathrm{N}$ & $\mathrm{N}$ & $\mathrm{Y}$ & $\mathrm{N}$ & $\mathrm{N}$ & $\mathrm{N}$ & $\mathrm{N}$ \\
\hline Race by Age by Year FEs & $\mathrm{N}$ & $\mathrm{N}$ & $\mathrm{N}$ & $\mathrm{Y}$ & $\mathrm{N}$ & $\mathrm{N}$ & $\mathrm{N}$ \\
\hline Exact Match on Turnout & $\mathrm{N}$ & $\mathrm{N}$ & $\mathrm{N}$ & $\mathrm{N}$ & $\mathrm{Y}$ & $\mathrm{Y}$ & $\mathrm{Y}$ \\
\hline Exact Match on Race & $\mathrm{N}$ & $\mathrm{N}$ & $\mathrm{N}$ & $\mathrm{N}$ & $\mathrm{N}$ & $\mathrm{Y}$ & $\mathrm{Y}$ \\
\hline Exact Match on Age Bin & $\mathrm{N}$ & $\mathrm{N}$ & $\mathrm{N}$ & $\mathrm{N}$ & $\mathrm{N}$ & $\mathrm{N}$ & $\mathrm{Y}$ \\
\hline
\end{tabular}

Robust standard errors clustered by individual in parentheses. Main effects for No DMV Match and 2016 are absorbed by fixed effects. Exact matching on turnout matches units based on each primary and general election from the 2008 primary through the 2014 general. For exact matching on age, we construct a separate age bin for each group of voters who were under 18 for a given set of elections, so the cohort of voters who became newly eligible to participate in 2010, 2012, 2014, and 2016 each have their own age bin. For voters who were eligible for all elections since 2008, we construct age deciles. 


\section{A.8 Effect of Voter ID Law, by Pre-Treatment Turnout}

Looking at the first entry in Table A.5, for example, we estimate the difference in turnout among those without ID and those with ID only among voters who had not previously voted in any primary or general election from 2008-2014. We find that the difference in 2016 primary turnout for these types of voters is just 0.4 percentage points. This group has a low baseline probability of voting, so there are few voters who could be deterred from voting because they lack identification. Similarly, looking at the last entry in Table A.5, the effect of the voter ID law on turnout among those without ID is just 1.1 percentage points for voters who have voted in every primary and general election from 2008-2014. For voters who regularly turnout to vote the voter ID law is an insufficient barrier to deter these voters from participating. For example, voters in this group may have been motivated to obtain valid identification before the 2016 primary or they might use no-excuse absentee voting, which does not require presenting a photo ID.

In contrast to those who rarely or always turnout, we find large effects among voters who only occasionally turnout to vote. Among those voters who only participated half of the elections they were eligible to participate in, 2 primary and 2 general elections from 2008-2014, we find a 3.7 percentage point effect of the voter ID laws. The estimates are much noisier in the lower left portion of the table because there are very few treated units who turn out to vote in many primary elections but very few general elections - and there are no treated units who voted in every primary election but no general election from 2008 through 2014.

Table A.6 shows how the effect of the voter ID law on general election turnout varies with an individual's prior turnout history. Again, we find that the voter ID law had a smaller effect among those who rarely participated in previous elections or those who always turned out to vote. The voter ID law caused a 2.3 and 0.8 percentage point decline in 2016 general election turnout among those who voted in no elections and in all elections before the ID law was implemented, respectively. Again, we find a much larger effect for voters who only participate occasionally in elections: among those who participated in half of the potential elections we find a 5.4 percentage decrease in turnout. 
Table A.5 - Effect of Voter ID Law on 2016 Primary Election Turnout, by Pre-Treatment Turnout.

\begin{tabular}{|c|c|c|c|c|c|}
\hline & \multicolumn{5}{|c|}{ \# of Pre-Treatment General Elections } \\
\hline & 0 & 1 & 2 & 3 & 4 \\
\hline \multicolumn{6}{|c|}{ \# of Pre-Treatment Primary Elections } \\
\hline 0 & $\begin{array}{c}-0.004 \\
(0.000)\end{array}$ & $\begin{array}{l}-0.008 \\
(0.000)\end{array}$ & $\begin{array}{l}-0.006 \\
(0.000)\end{array}$ & $\begin{array}{l}-0.020 \\
(0.001)\end{array}$ & $\begin{array}{r}-0.018 \\
(0.001)\end{array}$ \\
\hline 1 & $\begin{array}{l}-0.010 \\
(0.001)\end{array}$ & $\begin{array}{l}-0.023 \\
(0.001)\end{array}$ & $\begin{array}{l}-0.023 \\
(0.001)\end{array}$ & $\begin{array}{l}-0.029 \\
(0.001)\end{array}$ & $\begin{array}{r}-0.019 \\
(0.001)\end{array}$ \\
\hline 2 & $\begin{array}{l}-0.010 \\
(0.014)\end{array}$ & $\begin{array}{c}-0.017 \\
(0.006)\end{array}$ & $\begin{array}{c}-0.037 \\
(0.003)\end{array}$ & $\begin{array}{c}-0.031 \\
(0.002)\end{array}$ & $\begin{array}{r}-0.021 \\
(0.001)\end{array}$ \\
\hline 3 & $\begin{array}{l}-0.018 \\
(0.065)\end{array}$ & $\begin{array}{l}-0.008 \\
(0.017)\end{array}$ & $\begin{array}{l}-0.027 \\
(0.006)\end{array}$ & $\begin{array}{l}-0.036 \\
(0.003)\end{array}$ & $\begin{array}{r}-0.015 \\
(0.000)\end{array}$ \\
\hline 4 & & $\begin{array}{c}0.005 \\
(0.005)\end{array}$ & $\begin{array}{l}-0.012 \\
(0.004)\end{array}$ & $\begin{array}{c}-0.017 \\
(0.002)\end{array}$ & $\begin{array}{r}-0.011 \\
(0.000)\end{array}$ \\
\hline
\end{tabular}

Each cell estimates the effect of the voter ID law on 2016 primary turnout, estimating the effect separately for different pre-treatment turnout patterns. We construct strata of treated and control units based on the total number of times a voter casted a ballot in a pre-treatment primary election (2008-2014) and pre-treatment general election (2008-2014). We implement the same exact matching procedure described in Section 3. Robust standard errors are in parentheses. 
Table A.6 - Effect of Voter ID Law on 2016 General Election Turnout, by Pre-Treatment Turnout.

\begin{tabular}{|c|c|c|c|c|c|}
\hline & \multicolumn{5}{|c|}{ \# of Pre-Treatment General Elections } \\
\hline & 0 & 1 & 2 & 3 & 4 \\
\hline \multicolumn{6}{|c|}{ \# of Pre-Treatment Primary Elections } \\
\hline 0 & $\begin{array}{l}-0.023 \\
(0.000)\end{array}$ & $\begin{array}{l}-0.050 \\
(0.000)\end{array}$ & $\begin{array}{l}-0.045 \\
(0.001)\end{array}$ & $\begin{array}{l}-0.038 \\
(0.001)\end{array}$ & $\begin{array}{r}-0.016 \\
(0.001)\end{array}$ \\
\hline 1 & $\begin{array}{l}-0.039 \\
(0.002)\end{array}$ & $\begin{array}{l}-0.060 \\
(0.002)\end{array}$ & $\begin{array}{l}-0.055 \\
(0.002)\end{array}$ & $\begin{array}{l}-0.039 \\
(0.002)\end{array}$ & $\begin{array}{r}-0.014 \\
(0.000)\end{array}$ \\
\hline 2 & $\begin{array}{l}-0.048 \\
(0.010)\end{array}$ & $\begin{array}{l}-0.047 \\
(0.006)\end{array}$ & $\begin{array}{l}-0.054 \\
(0.004)\end{array}$ & $\begin{array}{l}-0.039 \\
(0.002)\end{array}$ & $\begin{array}{r}-0.012 \\
(0.000)\end{array}$ \\
\hline 3 & $\begin{array}{c}0.005 \\
(0.005)\end{array}$ & $\begin{array}{l}-0.073 \\
(0.026)\end{array}$ & $\begin{array}{l}-0.045 \\
(0.009)\end{array}$ & $\begin{array}{l}-0.040 \\
(0.003)\end{array}$ & $\begin{array}{r}-0.009 \\
(0.000)\end{array}$ \\
\hline 4 & & $\begin{array}{l}-0.057 \\
(0.101)\end{array}$ & $\begin{array}{l}-0.031 \\
(0.021)\end{array}$ & $\begin{array}{l}-0.022 \\
(0.002)\end{array}$ & $\begin{array}{r}-0.008 \\
(0.000)\end{array}$ \\
\hline
\end{tabular}

Each cell estimates the effect of the voter ID law on 2016 primary turnout, estimating the effect separately for different pre-treatment turnout patterns. We construct strata of treated and control units based on the total number of times a voter casted a ballot in a pre-treatment primary election (2008-2014) and pre-treatment general election (2008-2014). We implement the same exact matching procedure described in Section 3. Robust standard errors are in parentheses. 


\section{A.9 Exploring Heterogeneity in the Effect by Race and Party Registration}

In this section, we explore heterogeneity in the effect of the voter ID law for primary elections.

First, in Table A.7 we estimate whether the effect of the voter ID law varies by race, but we use primary election turnout as the outcome rather than general election turnout, as in Table 6 in the main body of the paper. Similar to the effects in general elections, we do not find evidence that the effect of the law varies substantially by race as we implement our most stringent specification (column 7).

Table A.7 - Effect of Voter ID Law on Primary Election Turnout Among Those Without ID, Individual Level, 2008-2016.

\begin{tabular}{|c|c|c|c|c|c|c|c|}
\hline & \multicolumn{7}{|c|}{ Voted in Primary (0-1) } \\
\hline & $(1)$ & $(2)$ & $(3)$ & (4) & $(5)$ & $(6)$ & $(7)$ \\
\hline No $\mathrm{DMV}^{*} 2016$ & $\begin{array}{l}-0.071 \\
(0.001)\end{array}$ & $\begin{array}{l}-0.083 \\
(0.001)\end{array}$ & $\begin{array}{l}-0.040 \\
(0.001)\end{array}$ & $\begin{array}{l}-0.050 \\
(0.001)\end{array}$ & $\begin{array}{c}-0.009 \\
(0.001)\end{array}$ & $\begin{array}{l}-0.011 \\
(0.001)\end{array}$ & $\begin{array}{r}-0.008 \\
(0.001)\end{array}$ \\
\hline No DMV * $2016 *$ Black & $\begin{array}{l}-0.019 \\
(0.001)\end{array}$ & $\begin{array}{c}0.023 \\
(0.002)\end{array}$ & $\begin{array}{c}-0.030 \\
(0.001)\end{array}$ & $\begin{array}{c}0.008 \\
(0.002)\end{array}$ & $\begin{array}{l}-0.003 \\
(0.001)\end{array}$ & $\begin{array}{c}0.005 \\
(0.002)\end{array}$ & $\begin{array}{c}0.004 \\
(0.002)\end{array}$ \\
\hline No DMV * $2016 *$ Hispanic & $\begin{array}{c}0.020 \\
(0.003)\end{array}$ & $\begin{array}{c}0.019 \\
(0.003)\end{array}$ & $\begin{array}{l}-0.014 \\
(0.003)\end{array}$ & $\begin{array}{c}-0.011 \\
(0.003)\end{array}$ & $\begin{array}{c}0.006 \\
(0.001)\end{array}$ & $\begin{array}{c}0.002 \\
(0.004)\end{array}$ & $\begin{array}{r}-0.000 \\
(0.004)\end{array}$ \\
\hline No DMV * $2016 *$ Other NW & $\begin{array}{l}-0.009 \\
(0.003)\end{array}$ & $\begin{array}{c}0.028 \\
(0.003)\end{array}$ & $\begin{array}{l}-0.037 \\
(0.003)\end{array}$ & $\begin{array}{c}-0.002 \\
(0.003)\end{array}$ & $\begin{array}{c}0.000 \\
(0.001)\end{array}$ & $\begin{array}{c}0.004 \\
(0.004)\end{array}$ & $\begin{array}{c}0.001 \\
(0.004)\end{array}$ \\
\hline $\mathrm{N}$ & $33,136,560$ & $33,136,560$ & $33,089,505$ & $33,089,485$ & $33,136,560$ & $33,136,560$ & $33,089,505$ \\
\hline \# Voters & $6,627,312$ & $6,627,312$ & $6,617,901$ & $6,617,897$ & $6,627,312$ & $6,627,312$ & $6,617,901$ \\
\hline Individual FEs & $\mathrm{Y}$ & $\mathrm{Y}$ & $\mathrm{Y}$ & $\mathrm{Y}$ & $\mathrm{N}$ & $\mathrm{N}$ & $\mathrm{N}$ \\
\hline Year FEs & $\mathrm{Y}$ & $\mathrm{N}$ & $\mathrm{N}$ & $\mathrm{N}$ & $\mathrm{Y}$ & $\mathrm{Y}$ & Y \\
\hline Race by Year FEs & $\mathrm{N}$ & $\mathrm{Y}$ & $\mathrm{N}$ & $\mathrm{N}$ & $\mathrm{N}$ & $\mathrm{N}$ & $\mathrm{N}$ \\
\hline Age by Year FEs & $\mathrm{N}$ & $\mathrm{N}$ & $\mathrm{Y}$ & $\mathrm{N}$ & $\mathrm{N}$ & $\mathrm{N}$ & $\mathrm{N}$ \\
\hline Race by Age by Year FEs & $\mathrm{N}$ & $\mathrm{N}$ & $\mathrm{N}$ & $\mathrm{Y}$ & $\mathrm{N}$ & $\mathrm{N}$ & $\mathrm{N}$ \\
\hline Exact Match on Turnout & $\mathrm{N}$ & $\mathrm{N}$ & $\mathrm{N}$ & $\mathrm{N}$ & $\mathrm{Y}$ & $\mathrm{Y}$ & $\mathrm{Y}$ \\
\hline Exact Match on Race & $\mathrm{N}$ & $\mathrm{N}$ & $\mathrm{N}$ & $\mathrm{N}$ & $\mathrm{N}$ & $\mathrm{Y}$ & $\mathrm{Y}$ \\
\hline Exact Match on Age Bin & $\mathrm{N}$ & $\mathrm{N}$ & $\mathrm{N}$ & $\mathrm{N}$ & $\mathrm{N}$ & $\mathrm{N}$ & $\mathrm{Y}$ \\
\hline
\end{tabular}

Robust standard errors clustered by individual in parentheses. Main effects for No DMV Match and 2016 are absorbed by fixed effects. Exact matching on turnout matches units based on all primary and general elections from 2008-2014. For exact matching on age, we construct a separate age bin for each group of voters who were under 18 for a given set of elections, so the cohort of voters who became newly eligible to participate in 2010, 2012, 2014, and 2016 each have their own age bin. For voters who were eligible for all elections since 2008, we construct age deciles.

Next, in Table A.8 we explore whether the effect of the voter ID law varies by party in primary elections. Table A.9 shows the same results by party for the general election. We do not find evidence that the effect of the ID law is meaningfully different for Republicans, Democrats, and unaffiliated registrants. Again, we stress that homogeneity in the effect size does not mean that the law did not affect the composition of the electorate: because those without ID are more likely to be Democrats and unaffiliated voters than those with ID (Table 1), the law seems to have disproportionately deterred Democratic voters. Because those without ID are more likely to be Democrats voters than those with ID, the overall effect of the law decreased (albeit slightly) the share of Democratic voters in the electorate. 
Table A.8 - Effect of Voter ID Law on Primary Election Turnout Among Those Without ID, Individual Level, 2008-2016.

\begin{tabular}{|c|c|c|c|c|c|c|c|}
\hline & \multicolumn{7}{|c|}{ Voted in Primary (0-1) } \\
\hline & (1) & $(2)$ & $(3)$ & $(4)$ & $(5)$ & (6) & $(7)$ \\
\hline No DMV * 2016 & $\begin{array}{l}-0.048 \\
(0.002)\end{array}$ & $\begin{array}{l}-0.055 \\
(0.002)\end{array}$ & $\begin{array}{l}-0.016 \\
(0.002)\end{array}$ & $\begin{array}{l}-0.022 \\
(0.002)\end{array}$ & $\begin{array}{l}-0.008 \\
(0.001)\end{array}$ & $\begin{array}{l}-0.010 \\
(0.001)\end{array}$ & $\begin{array}{r}-0.009 \\
(0.001)\end{array}$ \\
\hline No DMV *2016 * Dem & $\begin{array}{l}-0.051 \\
(0.002)\end{array}$ & $\begin{array}{c}-0.031 \\
(0.002)\end{array}$ & $\begin{array}{l}-0.050 \\
(0.002)\end{array}$ & $\begin{array}{c}-0.031 \\
(0.002)\end{array}$ & $\begin{array}{c}-0.004 \\
(0.001)\end{array}$ & $\begin{array}{c}0.000 \\
(0.001)\end{array}$ & $\begin{array}{c}0.001 \\
(0.001)\end{array}$ \\
\hline No DMV * $2016 *$ Unaffil & $\begin{array}{l}-0.007 \\
(0.002)\end{array}$ & $\begin{array}{c}-0.002 \\
(0.002)\end{array}$ & $\begin{array}{l}-0.041 \\
(0.002)\end{array}$ & $\begin{array}{c}-0.034 \\
(0.002)\end{array}$ & $\begin{array}{c}-0.001 \\
(0.001)\end{array}$ & $\begin{array}{c}0.002 \\
(0.001)\end{array}$ & $\begin{array}{c}0.002 \\
(0.001)\end{array}$ \\
\hline $\mathrm{N}$ & $33,136,560$ & $33,136,560$ & $33,089,505$ & $33,089,485$ & $33,136,560$ & $33,136,560$ & $33,089,505$ \\
\hline \# Voters & $6,627,312$ & $6,627,312$ & $6,617,901$ & $6,617,897$ & $6,627,312$ & $6,627,312$ & $6,617,901$ \\
\hline Individual FEs & $\mathrm{Y}$ & $\mathrm{Y}$ & $\mathrm{Y}$ & $\mathrm{Y}$ & $\mathrm{N}$ & $\mathrm{N}$ & $\mathrm{N}$ \\
\hline Year FEs & $\mathrm{Y}$ & $\mathrm{N}$ & $\mathrm{N}$ & $\mathrm{N}$ & $\mathrm{Y}$ & $\mathrm{Y}$ & $\mathrm{Y}$ \\
\hline Race by Year FEs & $\mathrm{N}$ & $\mathrm{Y}$ & $\mathrm{N}$ & $\mathrm{N}$ & $\mathrm{N}$ & $\mathrm{N}$ & $\mathrm{N}$ \\
\hline Age by Year FEs & $\mathrm{N}$ & $\mathrm{N}$ & $\mathrm{Y}$ & $\mathrm{N}$ & $\mathrm{N}$ & $\mathrm{N}$ & $\mathrm{N}$ \\
\hline Race by Age by Year FEs & $\mathrm{N}$ & $\mathrm{N}$ & $\mathrm{N}$ & $\mathrm{Y}$ & $\mathrm{N}$ & $\mathrm{N}$ & $\mathrm{N}$ \\
\hline Exact Match on Turnout & $\mathrm{N}$ & $\mathrm{N}$ & $\mathrm{N}$ & $\mathrm{N}$ & $\mathrm{Y}$ & $\mathrm{Y}$ & $\mathrm{Y}$ \\
\hline Exact Match on Race & $\mathrm{N}$ & $\mathrm{N}$ & $\mathrm{N}$ & $\mathrm{N}$ & $\mathrm{N}$ & $\mathrm{Y}$ & $\mathrm{Y}$ \\
\hline Exact Match on Age Bin & $\mathrm{N}$ & $\mathrm{N}$ & $\mathrm{N}$ & $\mathrm{N}$ & $\mathrm{N}$ & $\mathrm{N}$ & $\mathrm{Y}$ \\
\hline
\end{tabular}

Robust standard errors clustered by individual in parentheses. Main effects for No DMV Match and 2016 are absorbed by fixed effects. Exact matching on turnout matches units based on all primary and general elections from 2008-2014. For exact matching on age, we construct a separate age bin for each group of voters who were under 18 for a given set of elections, so the cohort of voters who became newly eligible to participate in 2010, 2012, 2014, and 2016 each have their own age bin. For voters who were eligible for all elections since 2008, we construct age deciles.

Table A.9 - Effect of Voter ID Law on General Election Turnout Among Those Without ID, Individual Level, 2008-2016.

\begin{tabular}{|c|c|c|c|c|c|c|c|}
\hline & \multicolumn{7}{|c|}{ Voted in General (0-1) } \\
\hline & (1) & $(2)$ & $(3)$ & (4) & $(5)$ & (6) & $(7)$ \\
\hline No DMV * 2016 & $\begin{array}{l}-0.127 \\
(0.002)\end{array}$ & $\begin{array}{l}-0.132 \\
(0.002)\end{array}$ & $\begin{array}{l}-0.086 \\
(0.002)\end{array}$ & $\begin{array}{c}-0.094 \\
(0.002)\end{array}$ & $\begin{array}{l}-0.031 \\
(0.001)\end{array}$ & $\begin{array}{l}-0.031 \\
(0.001)\end{array}$ & $\begin{array}{r}-0.028 \\
(0.001)\end{array}$ \\
\hline No DMV $* 2016 *$ Dem & $\begin{array}{l}-0.012 \\
(0.002)\end{array}$ & $\begin{array}{c}-0.002 \\
(0.002)\end{array}$ & $\begin{array}{l}-0.016 \\
(0.002)\end{array}$ & $\begin{array}{c}0.003 \\
(0.002)\end{array}$ & $\begin{array}{l}-0.002 \\
(0.001)\end{array}$ & $\begin{array}{l}-0.001 \\
(0.001)\end{array}$ & $\begin{array}{c}0.002 \\
(0.001)\end{array}$ \\
\hline No DMV * $2016 *$ Unaffil & $\begin{array}{c}0.054 \\
(0.002)\end{array}$ & $\begin{array}{c}0.042 \\
(0.002)\end{array}$ & $\begin{array}{l}-0.042 \\
(0.003)\end{array}$ & $\begin{array}{c}-0.036 \\
(0.003)\end{array}$ & $\begin{array}{c}0.001 \\
(0.001)\end{array}$ & $\begin{array}{c}0.002 \\
(0.001)\end{array}$ & $\begin{array}{c}0.003 \\
(0.001)\end{array}$ \\
\hline $\mathrm{N}$ & $33,136,560$ & $33,136,560$ & $33,089,505$ & $33,089,485$ & $33,136,560$ & $33,136,560$ & $33,089,505$ \\
\hline \# Voters & $6,627,312$ & $6,627,312$ & $6,617,901$ & $6,617,897$ & $6,627,312$ & $6,627,312$ & $6,617,901$ \\
\hline Individual FEs & $\mathrm{Y}$ & $\mathrm{Y}$ & $\mathrm{Y}$ & $\mathrm{Y}$ & $\mathrm{N}$ & $\mathrm{N}$ & $\mathrm{N}$ \\
\hline Year FEs & $\mathrm{Y}$ & $\mathrm{N}$ & $\mathrm{N}$ & $\mathrm{N}$ & $\mathrm{Y}$ & $\mathrm{Y}$ & $\mathrm{Y}$ \\
\hline Race by Year FEs & $\mathrm{N}$ & $\mathrm{Y}$ & $\mathrm{N}$ & $\mathrm{N}$ & $\mathrm{N}$ & $\mathrm{N}$ & $\mathrm{N}$ \\
\hline Age by Year FEs & $\mathrm{N}$ & $\mathrm{N}$ & $\mathrm{Y}$ & $\mathrm{N}$ & $\mathrm{N}$ & $\mathrm{N}$ & $\mathrm{N}$ \\
\hline Race by Age by Year FEs & $\mathrm{N}$ & $\mathrm{N}$ & $\mathrm{N}$ & $\mathrm{Y}$ & $\mathrm{N}$ & $\mathrm{N}$ & $\mathrm{N}$ \\
\hline Exact Match on Turnout & $\mathrm{N}$ & $\mathrm{N}$ & $\mathrm{N}$ & $\mathrm{N}$ & $\mathrm{Y}$ & $\mathrm{Y}$ & $\mathrm{Y}$ \\
\hline Exact Match on Race & $\mathrm{N}$ & $\mathrm{N}$ & $\mathrm{N}$ & $\mathrm{N}$ & $\mathrm{N}$ & $\mathrm{Y}$ & $\mathrm{Y}$ \\
\hline Exact Match on Age Bin & $\mathrm{N}$ & $\mathrm{N}$ & $\mathrm{N}$ & $\mathrm{N}$ & $\mathrm{N}$ & $\mathrm{N}$ & $\mathrm{Y}$ \\
\hline
\end{tabular}

Robust standard errors clustered by individual in parentheses. Main effects for No DMV Match and 2016 are absorbed by fixed effects. Exact matching on turnout matches units based on all primary and general elections from the 2008 primary through the 2014 general. For exact matching on age, we construct a separate age bin for each group of voters who were under 18 for a given set of elections, so the cohort of voters who became newly eligible to participate in 2010, 2012, 2014, and 2016 each have their own age bin. For voters who were eligible for all elections since 2008, we construct age deciles. 


\section{A.10 Effect of ID Law on Composition of Electorate}

To situate the vote reductions due to the voter ID law in a broader context we estimate how the law's effects changed the composition of the North Carolina electorate in the 2016 primary and general elections. In Table A.10 we show the racial and partisan composition of the North Carolina in the 2016 Primary and 2016 General election under the column "With Law." These are the observed shares of those who voted in each election. To estimate how the racial composition of the electorate would have changed had the ID law not been passed, we add the vote reductions from Table 7 - that is, the number of additional voters we estimate would have participated had the law not been passed - to the observed number of voters in each election. We show the estimated racial (Panel A) and partisan (Panel B) composition of the electorate under the counterfactual scenario without the voter ID law. It shows that, because the effects among those without ID are relatively small, along with the fact that those without ID make up a small portion of the electorate, these vote reductions have only a small effect on the overall composition of the electorate, at least along racial and partisan dimensions. We reiterate, that this interpretation of the findings requires relatively strong assumptions about voter behavior in the absence of the law. Specifically, that the law had no effect on the participation decision of those with the required identification.

\section{Table A.10 - Change in Composition of Electorate as a Function of ID Law}

\begin{tabular}{lcc|cc}
\hline \hline & \multicolumn{4}{c}{ A. Change in Racial Composition } \\
\cline { 2 - 5 } & \multicolumn{2}{c}{ 2016 Primary } & \multicolumn{2}{c}{ 2016 General } \\
\cline { 2 - 5 } & Without Law & With Law & Without Law & With Law \\
\hline White & $77.32 \%$ & $77.34 \%$ & $74.08 \%$ & $74.11 \%$ \\
Black & $19.34 \%$ & $19.32 \%$ & $21.56 \%$ & $21.54 \%$ \\
Hispanic & $1.07 \%$ & $1.07 \%$ & $1.49 \%$ & $1.49 \%$ \\
Other Non-White & $2.27 \%$ & $2.27 \%$ & $2.86 \%$ & $2.86 \%$ \\
\hline \multirow{4}{*}{ B. Change in Partisan Composition } \\
\cline { 2 - 5 } & \multicolumn{2}{c}{2016 Primary } & 2016 General \\
\cline { 2 - 5 } & Without Law & With Law & Without Law & With Law \\
\hline Democrat & $41.46 \%$ & $41.44 \%$ & $41.80 \%$ & $41.78 \%$ \\
Republican & $36.50 \%$ & $36.52 \%$ & $33.64 \%$ & $33.65 \%$ \\
Unaffiliated & $22.04 \%$ & $22.05 \%$ & $24.56 \%$ & $24.57 \%$ \\
\hline \hline
\end{tabular}

Note: Each cell presents our estimates of share of the electorate that belongs to a given category with and without the strict photo ID law. Panel A shows the change in the racial composition of the electorate, while Panel B shows the change in the partisan composition of the electorate as a function of the strict photo ID law. The first two columns show comparisons for the 2016 primary election, while the last two columns show comparisons for the 2016 general election 